University of Wollongong

Research Online

Faculty of Science, Medicine and Health -

Papers: Part B

Faculty of Science, Medicine and Health

$1-1-2019$

\title{
The latitudinal gradient of shell ornament - A case study from Changhsingian (Late Permian) brachiopods
}

Huiting Wu

China University of Geosciences, Peking University

G R. Shi

University of Wollongong, guang@uow.edu.au

Yuanlin Sun

Peking University

Follow this and additional works at: https://ro.uow.edu.au/smhpapers1

\section{Publication Details Citation}

Wu, H., Shi, G. R., \& Sun, Y. (2019). The latitudinal gradient of shell ornament - A case study from Changhsingian (Late Permian) brachiopods. Faculty of Science, Medicine and Health - Papers: Part B. Retrieved from https://ro.uow.edu.au/smhpapers1/851 


\title{
The latitudinal gradient of shell ornament - A case study from Changhsingian (Late Permian) brachiopods
}

\author{
Abstract \\ Although there have been many studies of biological patterns along latitude, less attention has been paid \\ on how latitude might affect the large-scale spatial patterns of ornament among shelled invertebrate \\ organisms. Based on a newly designed set of four quantitative metrics of shell ornaments and the \\ measurement and quantification of shell ornaments from 2654 Changhsingian (Late Permian) \\ brachiopods (representing 702 species) spanning $80^{\circ}$ south to $30^{\circ}$ north in paleolatitude, this paper \\ analyzes the relationship between the degree of shell ornament development of Changhsingian \\ brachiopods and paleolatitude. For the first time, we report the presence of statistically significant \\ latitudinal gradient patterns in the development of a multitude of brachiopod shell ornament types for the \\ Permian, generally characterized by the tendency of an increased proportion of brachiopods with more \\ complicated and stronger ornament towards the paleotropics. The gradient pattern is manifested not only \\ in the individual types of ornament (e.g., radial ornament, body spines) but also pronounced when all the \\ studied ornament types are integrated and analyzed together. Two scenarios are offered to account for \\ the latitudinal gradient of Changhsingian brachiopod shell ornaments. First, in consistency with most \\ previous similar studies, the latitudinal gradient of brachiopod shell ornament is explained by G. Vermeij's \\ escalation theory, in that shell ornaments are regarded as defence apparatuses against predation, and \\ that shell ornament of Changhsingian brachiopods is interpreted to have become stronger and more \\ elaborate in lower paleolatitudes as an adaptive response to the progressively increased predation \\ pressure towards the paleotropics. Second, the latitudinal gradient pattern of Changhsingian brachiopod \\ shell ornaments could also be explained by the varied calcification rate in the oceans as a function of the \\ latitudinal temperature gradient. The $\mathrm{CaCO} 3$ solubility is known to increase in colder, high-latitude areas. \\ This means it is more difficult for marine organisms to extract calcium carbonate to generate their shells \\ in higher latitudes, consequently resulting in less developed ornament for shelled marine benthic \\ organisms living in colder water habitats. This second interpretation potentially complements and \\ extends the G. Vermeij's escalation theory in explaining the observed latitudinal gradients of \\ Changhsingian brachiopod shell ornaments, but the theory itself requires both experimental and empirical \\ testing with respect to living shelled marine invertebrates and their production of shell ornament.

\section{Publication Details} \\ Wu, H., Shi, G. R. \& Sun, Y. (2019). The latitudinal gradient of shell ornament - A case study from \\ Changhsingian (Late Permian) brachiopods. Earth-Science Reviews, 197 102904-1-102904-10.
}


1 The latitudinal gradient of shell ornament - a case study from Changhsingian (Late Permian)

2

3

4 brachiopods

$$
\text { Huiting } \mathrm{Wu}^{1} \text {, G.R. Shi }{ }^{2} \text { *, Yuanlin } \text { Sun }^{1}
$$

${ }^{1}$ School of Earth and Space Sciences, Peking University, Beijing 100871, China

${ }^{2}$ School of Earth, Atmospheric and Life Sciences, University of Wollongong, Northfields Ave, NSW 2522, Australia (guang@uow.edu.au)

* Corresponding author

Abstract. Although there have been many studies of biological patterns along latitude, less attention has been paid on how latitude might affect the large-scale spatial patterns of ornament among shelled invertebrate organisms. Based on a newly designed set of four quantitative metrics of shell ornaments and the measurement and quantification of shell ornaments from 2654 Changhsingian (Late Permian) brachiopods (representing 702 species) spanning $80^{\circ}$ south to $30^{\circ}$ north in paleolatitude, this paper analyzes the relationship between the degree of shell ornament development of Changhsingian brachiopods and paleolatitude. For the first time, we report the presence of statistically significant latitudinal gradient patterns in the development of a multitude of brachiopod shell ornament types for the Permian, generally characterized by the tendency of an increased proportion of brachiopods with more complicated and stronger ornament toward the paleotropics. The gradient pattern is manifested not only in the individual types of ornament (e.g., radial ornament, body spines) but also pronounced when all the studied ornament types are integrated and analyzed together.

Two scenarios are offered to account for the latitudinal gradient of Changhsingian brachiopod shell ornaments. First, in consistency with most previous similar studies, the latitudinal gradient of brachiopod shell ornament is explained by G. Vermeij's escalation 
theory, in that shell ornaments are regarded as defence apparatuses against predation, and that shell ornament of Changhsingian brachiopods is interpreted to have become stronger and more elaborate in lower paleolatitudes as an adaptive response to the progressively increased predation pressure towards the paleotropics. Second, the latitudinal gradient pattern of Changhsingian brachiopod shell ornaments could also be explained by the varied calcification rate in the oceans as a function of the latitudinal temperature gradient. The $\mathrm{CaCO}_{3}$ solubility is known to increase in colder, high-latitude areas. This means it is more difficult for marine organisms to extract calcium carbonate to generate their shells in higher latitudes, consequently resulting in less developed ornament for shelled marine benthic organisms living in colder water habitats. This second interpretation potentially complements and extends the G. Vermeij's escalation theory in explaining the observed latitudinal gradients of Changhsingian brachiopod shell ornaments, but the theory itself requires both experimental and empirical testing with respect to living shelled marine invertebrates and their production of shell ornament.

Keywords: Changhsingian brachiopods; shell ornament; latitudinal gradient; escalation; calcification rate.

\section{Introduction}

The global latitudinal gradient is known to be a pervasive force in governing and regulating a plethora of biological (including evolutionary) and biogeographical processes and patterns (Schemske et al., 2009). Among these patterns, the global latitudinal gradient of biodiversity is clearly the best known and most extensively studied (Fischer, 1960; Willig et al., 2003). Other parallel but relatively less-studied latitude-related biotic patterns are represented by a 
number of long-recognized, albeit some still remaining controversial,

biological/biogeographical rules, including: the Bergmann's rule, the tendency of organisms to increase body size with latitude (Bergmann, 1847; Lomolino et al., 2006); Allen's rule, the tendency of vertebrates living in higher latitude and colder regions to grow shorter protruding body parts (e.g., beaks, tails, ears and legs) relative to their body size compared to counterparts living in a warmer climate (Allen, 1877; Lomolino et al., 2006); Jordan's rule, the tendency of marine fish to increase the number of vertebrae with increasing latitude (Jordan, 1892; Lomolino et al., 2006); and the Rapoport's rule, a tendency of species to increase their geographic ranges in higher latitude (Gaston et al., 1998; Veter et al., 2013). In this context, interestingly, relatively few studies have examined how latitude might affect the large-scale spatial patterns of shell ornament among shelled invertebrate organisms despite their prevalence and abundance in both the fossil record and present-day environments. The only possible exception to this observation is the presence of a body of studies concerning the variation of shell ornament in relation to latitude, which regards the degree of shell ornament as a response to predation pressure that increases with the decrease of latitude (e.g., Vermeij, 1977, 1978; Signor and Brett, 1984). In this case, shell ornament has been used as a means to test whether variation in the level of predation would follow a particular latitudinal gradient. Thus far, published evidences from both neontological and paleontological records seem to well support the hypothesis (neontological case studies: Stanley, 1970; Vermeij, 1987; Watson, 2009; paleontological case studies: Leighton, 1999; Dietl and Kelley, 2001), although rare exceptions also exist (Vörös, 2014). Among the paleontological case studies, Brachiopoda has been among the main clades for investigation, probably because of their possession of a diverse array of shell ornaments, coupled with a wide range of paleogeographic, paleoenvironmental and stratigraphic distributions, making them ideal materials for exploring the possible latitudeornament relationships. However, published information concerning the variation of 
brachiopod shell ornament in connection to paleolatitude is very limited and, to our knowledge, only available for the Devonian (Leighton, 1999), the Carboniferous (Dietl and Kelly, 2001), and the Jurassic (Vörös, 2014). Among these three previous studies, however, inconsistent patterns have been reported: for the two Paleozoic studies, both Leighton (1999) and Dietl and Kelly (2001) found that brachiopod ornament gradually increased towards lower paleolatitudes, as would be expected by the latitude-predation hypothesis; for the Jurassic, Vörös (2014) found that the distribution of two main types of ornament showed opposite trends (spinosity was confined to higher paleolatitudes whereas ribbing was somewhat stronger in low latitudes), partly contrary to the observations made for the Paleozoic case studies. To explain this discrepancy between the Paleozoic and Jurassic case studies within the framework of the latitude-predation hypothesis, Vörös (2014) suggested that the Jurassic gradient of the shellcrushing predation might be rather similar to that recorded in the mid-Paleozoic, while the drilling predation might prevail in the higher paleolatitudes in the Jurassic.

In this paper, we provide the first case study of the co-variation between brachiopod shell ornament and latitude for the Permian Period, using an array of newly designed and quantified ornament metrics applied to a comprehensively compiled and biostratigraphically wellresolved global database of Changhsingian (Late Permian) brachiopod species. The specific aims of this paper are twofold. First, we want to test which of the shell-ornament latitudinal relationships documented for the Devonian, Carboniferous and Jurassic holds also for the Permian. Second, given the ornament-latitude relationship revealed in this study, which could be either positive, negative or random (un-correlated), how should it be best explained? The basic hypothesis in the present study is that the relative strength of Permian brachiopod shell ornament was inversely correlated with latitude: that is, brachiopod shell ornament became stronger and more elaborate towards lower latitudes. An acceptance of this hypothesis thus would support (though not necessarily prove) the notion that predation pressure increases with 
decrease of latitude. A rejection of the hypothesis, on the other hand, would mean that the commonly perceived inverse ornament strength-latitude relationship needs to be reassessed and other possible mechanisms explored.

To our knowledge, this is the first such study undertaken for the Permian, although Zhang and $\mathrm{He}(2008)$ had carried out a study of the temporal patterns of Permian brachiopod ornament changes across the Permian-Triassic boundary based on a regional (South China) database. Changhsingian (last stage of the Permian Period) brachiopods are of considerable global interest because of their close association with the end-Permian mass extinction. For this reason, they have been extensively sampled and systematically described around the world, leading to a wealth of literature on their taxonomy and biostratigraphy, as well as excellent illustrations of a range of morphological characteristics (e.g., Chen et al., 2006; Shen and Shi, 2007; Posenato, 2011; Zhang et al., 2014; He et al., 2014, 2019; Wu et al., 2018a), enabling the characterization and measurement of shell ornament on a large spatial scale. Not surprisingly, in addition to Zhang and He (2008), several other studies have also specifically addressed the global Changhsingian brachiopod fauna as a whole, respectively connected to their global paleobiogeography (Shen et al., 2001), global nearshore-offshore body-size change patterns (Shi et al., 2016), as well as extinction and survival patterns (Chen et al., 2005; Posenato et al., 2009; He et al., 2015; Zhang et al., 2016; Wu et al., 2018b), but none has specifically explored the latitudinal patterns of shell ornament. In this sense, the present study may be regarded as both a complementary and a supplementary contribution to the existing knowledge concerning the global Changhsingian brachiopod fauna.

\section{Data and methods}

2.1. The global Changhsingian brachiopod database 

up to the end of 2016, built on and expanded from an earlier version of the same database used by Shi et al. (2016). The database encompasses a range of basic information, including order name, family name, genus name, species name, collection localities, age and age range, paleolatitude, length and width of shell, as well as shell ornament types (hinge spine, body spine, costa and ruga) and frequency (density), mostly directly extracted from the original references with the exception of paleolatitude. Paleolatitude for each Changhsingian brachiopod locality was obtained either directly from the original literature or, if no such data were available, calculated using the software PointTracker (Scotese, 2004). The final dataset contains 702 brachiopod species and 2654 specimens, extending from $80^{\circ}$ south to $30^{\circ}$ north in paleolatitude (Fig. 1). All taxonomic classifications were checked and updated following the 2007).

\subsection{Quantifying and estimating brachiopod shell ornament strength}

Brachiopods as a whole are a very diverse group with a great variety of ornament types (Cooper, 1970; Harper and Moran, 1997), most of which are difficult to quantify. Therefore, not surprisingly, there is yet no single quantitative ornament index developed that can capture the degree of variability of all ornaments in a given brachiopod shell. Presumably for this reason, previous studies of brachiopod ornaments have simply categorized ornament into four categories: (1) weak, ornament absent (i.e., shells smooth) or capillate; (2) costate ornament; (3) strongly costate, rugose, or plicate ornament; and (4) spinose ornament anterior to hingeline (Leighton, 1999; Dietl and Kelly, 2001; Vörös, 2010, 2014), with the implication that the larger the category number the stronger the ornament represented. This classification scheme may be 
appropriate for certain selected brachiopod taxa, as it was in the case of Leighton (1999) and also Dietl and Kelly (2001), both of which were focused on planoconvex strophomenates and excluded chonetides; or as in the case of Vörös (2014), which only referred to Jurassic biconvex rhynchonellides and terebratulides. This relatively simple treatment of shell ornament classification is considered inappropriate for the present study because Changhsingian brachiopods are very diverse ( $>700$ species) with a great proliferation of ornaments. Consequently, we use a new approach, carried out in a multitude of consequential steps. First, similar to some previous studies (Leighton, 1999; Zhang and He, 2008), brachiopod ornaments were categorized into four broad groups: hinge spine, body spine (excluding hinge spine), costa (radial ornament), ruga (concentric ornament) (Fig. 2; Table 1). Second, for each of these categories, we then measured the frequency (i.e., density per centimetre) of each of these ornament types: frequency of hinge spine was measured along the hingeline while that for the other three ornament types was measured on the middle-valve of a specimen. For each such measurement, the frequency of an ornament type was obtained, in most cases, from the ventral 
complex ornament, and then to plot this ratio over a gradient of evenly spaced latitudinal bins.

If a latitudinal gradient in the variation of ornament strength is apparent, a significant trend should be detectable with an appropriate statistical test (see below). To facilitate this analysis and also considering the range of ornament types concerned in this paper, four different ornament metrics were quantified and calculated (Table 2). First, we devised a single ornament complexity index (OCI), integrating all four ornament types (hinge spine, body spine, costa and ruga) included in Table 1, defined as the percentage of the number of specimens with no ornament or only one type of ornament over the number of specimens with more than one type of ornament (Table 2, Supplementary Data Table 1). In addition to OCI, the degree of shell ribbing (radial ornament) and spinosity was also considered but treated separately to allow further comparison, each with its own index (Table 2). Thus, the radial ornament index, or ROI, refers to the degree of shell ribbing, quantified as the percentage of the number of specimens with radial ornament frequency equal to or less than $10 / \mathrm{cm}$ to the number of specimens with radial ornament frequency more than 10/cm (see Supplementary Data Table 2). In a similar manner, the body spine index (BSI) describes the degree of shell spinosity demonstrated by body spines (i.e., excluding hinge spine), and was calculated as a ratio between the number of specimens with body spine frequency equal to or less than $8 / \mathrm{cm}$ and the number of specimens with body spine frequency more than $8 / \mathrm{cm}$ (see Supplementary Data Table 3). Finally, a composite ornament index, or COI, was also employed as a proxy of the overall degree of out that in calculating OCI, ROI and BSI the cut-off point between two broad groups of ornament in each case was randomly chosen. This approach is admittedly arbitrary, but is consistent with some other comparable studies (Linse et al., 2006; Powell and Glazier, 2017). 

degrees, following Dietl and Kelly (2001), but for the analysis of COI, because a greater spatial resolution was possible as the data used for this analysis combine frequencies of all ornament types which allowed the inclusion of more collections for the analysis, we conducted an analysis and comparison of COIs at two different levels of spatial scaling: one at 20-degree latitudinal intervals, the other at 10-degree latitudinal intervals.

\subsection{Statistical analyses}

To test whether the degree of brachiopod shell ornament variation followed a latitudinal gradient during the Changhsingian, we used the two-tailed Cochran-Armitage Z-statistic-based trend test. This is a special test designed for categorical data and has been used for similar studies (Sanvito et al., 2007; Gardner et al., 2016; Mack et al., 2018). Such a test was conducted respectively on the ornament complexity index (OCI), radial ornament index (ROI) and body spine index (BSI) (Table 2, Figs. 3, 4, 5). Since the Cochran-Armitage trend test could not be performed for regions containing less than three latitudinal bins, no such tests were possible for the northern hemisphere where there are only two latitudinal bins with Changhsingian brachiopod occurrences.

When comparing the composite ornament index (COI) between latitudinal bins, which uses frequency data, an analysis of box plot was conducted and pairwise differences between adjacent latitudinal bins were compared with the Mann-Whitney U-test to check for statistical significance. Because this test is not constrained by the number of latitudinal bins in each hemisphere, a comparison of the two latitudinal bins in the northern hemisphere was possible (Fig. 6). 
To further investigate the relations between ornament frequency and latitude, correspondence analysis (CA) was adopted and conducted on the data matrix containing the frequency distribution, expressed by number of specimens, of COI categories at two different spatial scales, respectively at 20-degree and 10-degree latitudinal bins (see Supplementary Data Tables 4-5). In this exercise, the COI was divided into four graded categories in an ascending order of ornament complexity: category 1 has $\mathrm{COI}<10$, category 2 with $\mathrm{COI}$ ranging between 10 and 30, category 3 with COI falling between 31 and 50, and category 4 with COI $>50$ (Figs categories in a latitudinal bin constitutes a profile specific to the latitudinal bin, and these profiles are here depicted as pie charts (Fig. 9). To test for statistically significant differences between profiles (i.e., between paleolatitudinal bins), chi-square distances between each profile and the mean profile (Table 3) as well as the chi-square distances between each pair of profiles (Table 4) were calculated. The mean profile was conceptualized as the centre of axes, where there is no difference between profiles (Greenacre, 2007; Alberti, 2013). The comparison of profiles was used to verify the results derived from CA, which used essentially the same data matrix (see Supplementary Data Table 5), but was conducted at a higher spatial resolution using 10-degree latitudinal bins. This is possible because if two latitudinal bins have similar profiles, they would plot close together in the CA plot. A similar CA was also used by Dietl and Kelly (2001) in a comparable study. To see how closely the latitudinal variation of ornament (expressed by the pie diagrams of profiles) tracks paleolatitude, a linear regression analysis was conducted with the line of best fit and $r^{2}$ values obtained and depicted (Fig. 9).

The Cochran-Armitage trend test and correspondence analysis were performed using XLSTAT (www.xlstat.com/en/) while the Box plot, Mann-Whitney U-test and linear regression analysis were performed using PAST (Hammer et al., 2001). For all the statistical comparisons between paleolatitudinal bins with respect to a particular ornament index, a 
significant result means that the proportion of specimens bearing a particular type of ornament is dependent on latitude, thus confirming the hypothesis that a latitudinal gradient in ornament existed.

\section{Results}

For the ornament complexity index (OCI), our analysis shows that there is a significant latitudinal gradient, with the proportions of brachiopod specimens with no or only one type of ornament increasing with paleolatitude in the southern hemisphere (Cochran-Armitage trend test, $p<0.05$ ) (Fig. 3) (note that Changhsingian brachiopods in the northern hemisphere fall into only two latitudinal bins, thus insufficient for a Cochran-Armitage trend test, hence no northern hemisphere data can be shown in Fig. 3; same reason for ROI and BSI analyses, see below). In other words, Changhsingian brachiopods living in lower latitudes tended to have a significantly higher proportion of individuals with a greater diversity of shell ornament types. The relationships of brachiopod radial ornament (ROI) and body spine (BSI) with respect to paleolatitude were separately investigated, both of which decreased in frequency as latitude increased, thus demonstrating a significant latitudinal gradient (Fig. 4 shows a significant trend for ROI at $p<0.05$; Fig. 5 shows a significant trend for BSI at $p<0.05$ ). For instance, the high latitudinal area $\left(60^{\circ}-80^{\circ} \mathrm{S}\right.$ paleolatitudinal bin) contains over four times more specimens with sparse radial ornament than those of the paleo-equatorial area $\left(0^{\circ}-20^{\circ} \mathrm{S}\right.$ paleolatitudinal bin $)$ (Fig. 4). Although the proportion of specimens with body spine frequency equal to or less than $8 / \mathrm{cm}$ in the $20^{\circ}-40^{\circ} \mathrm{S}$ paleolatitudinal band is higher than that in the $60^{\circ}-40^{\circ} \mathrm{S}$ paleolatitudinal band, there is still an overall significant trend of decreasing proportions of specimens with sparse body spines as latitude decreased in the southern hemisphere (Cochran-Armitage trend test at $p<0.05)$ (Fig. 5). 

COI median values from $80^{\circ}-60^{\circ} \mathrm{S}$ to $60^{\circ}-40^{\circ} \mathrm{S}$, and from $60^{\circ}-40^{\circ} \mathrm{S}$ to $40^{\circ}-20^{\circ} \mathrm{S}$ (MannWhitney U-test with $p<0.05$ ), as well as an increase of COI median values from $40^{\circ}-20^{\circ} \mathrm{S}$ to $20^{\circ}-0^{\circ} \mathrm{S}$, the latter matched by a significant increase of COI median values from $40^{\circ}-20^{\circ} \mathrm{N}$ to $20^{\circ}-0^{\circ} \mathrm{N}$ (Mann-Whitney U-test with $p<0.05$ ). The consistent paleolatitudinal trends of COI suggest that the degree of overall brachiopod shell ornament, expressed by integrating the relative frequencies of hinge spine, body spine, radial ribbing and concentric ruga, increased towards lower paleolatitudes, a pattern that is conspicuously displayed in Figure 6 .

Correspondence analysis (CA) of the data matrix consisting of COI and 20-degree paleolatitudinal bins (Fig. 7) shows that the distribution of the paleolatitudinal bins is partitioned into three areas, each constrained by a specific range of COI values. In the $80^{\circ}-$ $60^{\circ} \mathrm{S}$ and $60^{\circ}-40^{\circ} \mathrm{S}$ paleolatitudinal bins, brachiopods had a higher proportion of specimens with COI smaller than 10 ; by comparison, brachiopods from the $40^{\circ}-20^{\circ} \mathrm{S}$ and $40^{\circ}-20^{\circ} \mathrm{N}$ areas had a higher proportion of specimens with COI ranging from 10 to 30 , and those from $20^{\circ}-0^{\circ} \mathrm{S}$ and $0^{\circ}-20^{\circ} \mathrm{N}$ areas had a higher proportion of specimens with COI larger than 30 . Another notable feature of the CA biplot is the disposition of paleolatitudinal bins and COI values with respect to the first principal axis (F1) of the CA biplot (Fig. 7): COI values decrease as F1 $20^{\circ} \mathrm{N}$ ) are disposed to the most negative end of F1. As such, one inescapable conclusion from this pattern of polarized depiction of the data points is that the COI values are inversely correlated with paleolatitude with respect to $\mathrm{F} 1$, which accounts for $60.2 \%$ of the total variance of the data; in other words, the proportion of brachiopods with more complex ornament (i.e., higher COI values) decreased with an increase of paleolatitude. 
To verify whether or not this observation is dependent on the choice of the paleolatitudinal bin size (i.e., the size of samples for comparison), we conducted a CA on a similar data matrix but with a finer paleolatitudinal gradient, at $10^{\circ}$ bins. The result of this analysis is shown in Figure 8: in high paleolatitudinal areas $\left(80^{\circ}-70^{\circ} \mathrm{S}\right.$ and $\left.60^{\circ}-50^{\circ} \mathrm{S}\right)$ a higher proportion of brachiopods had COI smaller than 10 ; in middle latitudinal area $\left(50^{\circ}-40^{\circ} \mathrm{S}, 30^{\circ}-20^{\circ} \mathrm{S}\right.$ and $20^{\circ}-$ $\left.30^{\circ} \mathrm{N}\right)$, a higher proportion of brachiopod had COI at $10-30$; in low latitudinal areas $\left(10^{\circ}-0^{\circ} \mathrm{S}\right.$, $0^{\circ}-10^{\circ} \mathrm{N}$ and $10^{\circ}-20^{\circ} \mathrm{N}$ ), a higher proportion of brachiopod had COI larger than 30 .

Notably, the patterns revealed in Figure 8 are also corroborated by tests of the chi-square distances between the profile of each 10-degree paleolatitudinal bin and their mean profile (Table 3, Fig. 9), showing a progressive drop in pairwise distance towards the paleo-equator in both hemispheres, with the exception of the $20^{\circ}-10^{\circ} \mathrm{S}$ paleolatitudinal bin. This bin possibly is a statistical outlier because it is also shown to be out of place in Figure 8 when compared to the dispositioning of the other 10-degree paleolatitudinal bins. In Table 4, which compares the chi-square distances between all pairs of paleolatitudinal bins, a consistent feature is that the distances between neighbouring pairs of paleolatitudinal bins are generally shorter than when they are farther apart, suggesting that the COI profile of a paleolatitudinal bin is most similar to its nearest bin (see also Fig. 9). As was found in Table 3, one possible outlier here is the $10^{\circ}-20^{\circ} \mathrm{N}$ paleolatitudinal bin.

In brief, results of both CA biplots show that brachiopod ornament frequency, as expressed by COI values, decreased as latitude increased (Fig. 7, 8), and this pattern is particularly obvious in Figure 6 where the secular COI decline from the middle paleolatitudinal zone $\left(20^{\circ}-\right.$ $\left.40^{\circ} \mathrm{S}\right)$ through to the high $\left(60^{\circ}-80^{\circ} \mathrm{S}\right)$ paleolatitudinal zone was found statistically significant (Mann-Whitney test, $\mathrm{p}<0.05$ ) (while the $\mathrm{COI}$ change between $0^{\circ}-20^{\circ} \mathrm{S}$ and $20^{\circ}-40^{\circ} \mathrm{S}$ paleolatitudinal zones is statistically insignificant, albeit still displaying a small decline). Furthermore, the progressive decline in the degree of shell ornament towards higher latitudes 
appears to be a rather robust pattern because (1) it seems independent of the spatial scaling used for testing (similar patterns were revealed at two different paleolatitudinal scales), and (2) it is strongly corroborated by the highly linear distribution of the COI profiles when plotted with respect to paleolatitudes and their mutual chi-square distances (Tables 3, 4; Fig. 9)

\section{Discussion}

Despite using a different methodology in quantifying shell ornament and a different taxonomic and chronostratigraphic dataset, the results of our study support the conclusions reached in two previous studies focused on mid-Paleozoic brachiopods (Leighton, 1999; Dietl and Kelley, 2001), in both of which the degree of brachiopod shell ornament was found to decrease significantly with increasing latitude, a common biotic pattern that has also been noted for many living shelly benthos (Nicol, 1967; Vermeij, 1987; Trussell, 2000; Watson et al., 2012). This consistent pattern suggests that the latitudinal gradient of shell ornament is a pervasive and recurring feature at a global scale, and therefore it must have been driven and maintained by some persistent underlying ecological and/or evolutionary mechanisms. To date, two leading hypotheses have been proposed to account for the development of shell ornament, including predation (Leighton, 1999; Vörös, 2010, 2014) and calcification (solubility of $\mathrm{CaCO}_{3}$, Watson et al., 2012).

Predation. Among the published hypotheses, the most widely cited model is predation. In this scenario, the function of shell ornament is thought to serve as a defence system against predation and, therefore, the degree of ornament represents an adaptive response to the level of predation pressure at a particular location (habitat) at a particular time, leading to a dynamic 
positive relationship between predation pressure and ornament enhancement, the so-called escalation or "arms race" theory (Vermeij, 1987).

In modern marine ecosystems, numerous studies have shown that the degree of marine predation, mainly manifested by shell-crushing (durophages) and shell-drilling predators, increases towards the equatorial area, leading to the formation of a conspicuous latitudinal gradient of predation (Aronson et al., 2007; Schemske et al., 2009). Similarly, from the fossil record there also exists a large body of literature documenting a strong positive correlation between the degree of ornament of marine shelly benthos and the intensity of predation (e.g., Alexander, 1981, 1986; Harper and Skelton, 1993; Stone, 1998; Leighton, 1999; Dietl and Kelley, 2001; Zuschin et al., 2003; Klompmaker and Kelley, 2015). Most notable examples of these studies come from the Mesozoic-Cenozoic fossil record in support of the theory of the Mesozoic Marine Revolution (Vermeij, 1977). But, as initially suggested by Signor and Brett (1984) and later documented by Leighton (1999), the escalation between predation and shell ornament predated the Mesozoic Marine Revolution and actually began as early as in the Devonian, coinciding with the first major diversification of marine vertebrates during the Age of Fish. A subsequent study, undertaken by Dietl and Kelley (2001), raised two previously under-appreciated features of this escalation. First, it is apparent that the large-scale escalation between predation and ornament in the marine realm continued into the Carboniferous. Second, the strength of the latitudinal gradient of brachiopod ornament varied temporally during the Carboniferous, in that it was found most pronounced in the Tournaisian when the latitudinal temperature gradient was steepest.

Regarding the first feature highlighted in the Dietl and Kelley's study (2001) and considering the results from the present study, we may conclude that an active escalation between predation and the enhancement of anti-predatory ornament of brachiopods also prevailed for at least part of the Permian, namely the Changhsingian, the last stage of the 
Permian just prior to the end-Permian mass extinction. To evaluate the validity of this inference, we may refer to the empirical evidence of predation on Permian brachiopods to see if there indeed existed a significant latitudinal gradient in predation in the marine realm during the Permian. Such evidence may be provided by the relative frequency or intensity of predation of marine shelly invertebrate fossils in relation to paleolatitude. To our knowledge, to date no such global statistical study has been undertaken for the Permian despite a number of largescale studies on the temporal variation of marine predation through the Phanerozoic (e.g., Signor and Brett, 1984; Alexander, 1986; Kowalewski et al., 1998, 2005; Klompmaker et al., 2019). We attempted to collect the global predation data on Permian brachiopods, bivalves, gastropods and echinoids, mainly referring to drill holes and repair scars in fossil records which are commonly used in predation studies (Harper et al., 2009; Harper, 2016). Unfortunately, too few studies have been focused on such records (see Supplementary Data Table 6), and we were unable to collect sufficient data to permit a statistically robust analysis between marine predation intensity and paleolatitude during the Permian. Nevertheless, there is published evidence suggesting that (1) marine predation was ubiquitous across many environments and latitudes throughout the Permian, albeit relatively rare when compared with Mesozoic-Cenozoic molluscs (Kowalewski et al., 2000, 2005); and that (2) Permian bivalves from west Texas in the southwestern USA, then located in the northern subtropical zone, were drilled more intensely (drilling frequency $7.43 \%$ ) than Permian bivalves from Brazil and Greece (drilling frequency respectively $0.57 \%$ and about $1.5 \%$ ), both then located in the middle to high latitudes of Gondwana (Grant, 1988; Kowalewski et al., 2000; Hoffmeister et al., 2004). If the latter can be taken as an indication of at least a crude expression of a latitudinal gradient in marine predation for the Permian, the latitudinal gradient pattern of predation is certainly correlated with, and thus may account for, the conspicuous latitudinal gradient of 
Changhsingian brachiopod ornament found in the present study, thus confirming the existence of an active predator-prey escalation during at least part of the Permian.

Calcification. Concerning the coincidence between the latitudinal gradient of brachiopod ornament and a contemporaneous steep latitudinal temperature gradient, another important finding revealed by Dietl and Kelley's (2001) study, an inference can be drawn that temperature may also have some bearing on the degree of shell ornament development. The latitudinal gradient of global temperature variation is a well-known natural phenomenon, generally expressed as a function of declining solar insolation per unit area with increasing latitude (e.g., $\mathrm{Fu}$ and Rich, 1999). The mechanism by which the global latitudinal thermal gradient may potentially influence shell ornament formation and variation in relation to latitude is via the thermodynamic relationship between temperature and the solubility of calcium carbonate $\left(\mathrm{CaCO}_{3}\right)$ in seawater. Generally, $\mathrm{CaCO}_{3}$ and $\mathrm{CO}_{2}$ solubility decreases as temperature increases towards equatorial areas (Watson et al., 2012). Thus, it is perceivable and predictable that the higher $\mathrm{CaCO}_{3}$ solubility in colder marine environments will increase the energetic cost for calcification (Clarke, 1990, 1993). This makes it more difficult for marine organisms to produce calcium carbonate to generate their shells, including the production of shell ornaments. Although this scenario potentially could explain the observed latitudinal gradient pattern of Permian brachiopod ornament characterized by less developed ornament in higher-latitude brachiopods, the theory itself requires both experimental and empirical testing with respect to living marine invertebrates with calcified shells. We are not yet aware of any published studies as far as the relationship between latitude-related calcification rate and shell ornament development of living marine invertebrates is concerned. 
(1) A higher proportion of Changhsingian brachiopods living in higher paleolatitude habitats were found possessing smooth or only one type of ornament, compared to those inhabiting lower paleolatitudinal areas;

(2) Higher proportions of Changhsingian brachiopod shells with denser radial ornament (ribbing) and body spines were found in lower paleolatitudinal areas;

(3) The composite ornament index, comprised of the sum of hinge spine frequency, body spine frequency, radial ornament frequency and ruga frequency of Changhsingtian brachiopods, was found to decrease with increase of paleolatitude;

(4) The conspicuous latitudinal gradient patterns of Changhsingian brachiopods revealed in this study are comparable with the results of two previous studies focused on mid-Paleozoic (Devonian and Carboniferous, respectively) brachiopods;

(5) The latitudinal gradient patterns of Changhsingian brachiopods can be well explained by Vermeij's escalation theory, in that brachiopod ornaments are regarded as self-defense adaptations against predation, and thus an inversely correlated latitude-ornament gradient, such as the patterns revealed here for the Changhsingian brachiopods, could develop as a response to increased predation pressure towards the tropics;

(6) A second, probably or potentially complementary and supplementary explanation for the conspicuous latitudinal gradient patterns of Changhsingian brachiopods is the varying calcification rate of brachiopod shells in relation to latitude. This interpretation is based on the fact that $\mathrm{CaCO}_{3}$ and $\mathrm{CO}_{2}$ solubility increases with increasing latitude in marine environments, making it difficult for marine organisms to produce calcium carbonate to form shells and produce more elaborate shell ornament. This scenario may explain the observed latitudinal gradient pattern of Permian brachiopod ornament characterized by less developed ornament in 
higher-latitude brachiopods, but both experimental and empirical testing of this hypothesis is required.

\section{Acknowledgements}

We are very grateful for the constructive and helpful reviews by Elizabeth M. Harper, Lindsey R. Leighton, Attila Vörös and Roger Pierson. We thank Yang Zhang for helpful discussion on the paper. This study is supported by an Australian Research Council grant awarded to GRS (ARC DP150100690) and the China Postdoctoral Science Foundation (Grant No. 2019M650318).

Appendix A. Supplementary Data Tables 1-6

\section{References}

Alberti, G., 2013. Making sense of contingency tables in archaeology: The aid of correspondence analysis to intra-site activity areas research. Journal of Data Science 11, $479-499$.

Alexander, R.R., 1981. Predation scars preserved in Chesterian brachiopods: probable culprits and evolutionary consequences for the articulates. Journal of Paleontology 55, 192-203.

Alexander, R.R., 1986. Resistance to and repair of shell breakage induced by durophages in late Ordovician brachiopods. Journal of Paleontology 60, 273-285.

Allen, J.A., 1877. The influence of physical conditions in the genesis of species. Radical review 1, 108-140. 
Aronson, R.B., Thatje, S., Clarke, A., Peck, L.S., Blake, D.B., Wilga, C.D., Seibel, B.A., 2007. Climate change and invasibility of the Antarctic benthos. Annual Review of Ecology, Evolution, and Systematics 38, 129-154.

Bergmann, C. 1847. Ueber die Verhaltnisse der Warmeokonomie der Thiere zu ihrer Grosse. - Gottinger Studien 1, 595-708.

Chen, Z.Q., Kaiho, K., George, A.D., 2005. Survival strategies of brachiopod faunas from the end-Permian mass extinction. Palaeogeography, Palaeoclimatology, Palaeoecology 224, $232-269$.

Chen, Z.Q., Shi, G.R., Yang, F.Q., Gao, Y.Q., Tong, J.N., Peng, Y.Q., 2006. An ecologically mixed brachiopod fauna from Changhsingian deep-water basin of South China: consequence of end-Permian global warming. Lethaia 39, 79-90.

Clarke, A.,1990. Temperature and Evolution: Southern Ocean Cooling and the Antarctic Marine Fauna, in: Kerry, K.R., Hempel, G. (Eds.), Antarctic Ecosystems: Ecological Change and Conservation. Springer-Verlag, Berlin Heidelberg, pp. 9-22.

Clarke, A., 1993. Temperature and extinction in the sea: a physiologist's view. Paleobiology $19,499-518$.

Cooper, G. 1970. Generic Characters of Brachiopods, in: Yochelson, E.L. (Ed.), Proceedings of the north american paleontological convention. Allen Press, Lawrence, USA, pp. 194263.

Dietl, G.P., Kelley, P.H., 2001. Mid-Paleozoic latitudinal predation gradient: distribution of brachiopod ornamentation reflects shifting Carboniferous climate. Geology 29, 111-114.

Fischer A.G., 1960. Latitudinal variations in organic diversity. Evolution 14, 64-81. 
Fu, P., Rich, P.M., 1999. Design and implementation of the Solar Analyst: an ArcView extension for modeling solar radiation at landscape scales. Proceedings of the nineteenth annual ESRI user conference. San Diego, USA.

Gardner, E.E., Walker, S.E., Gardner, L.I., 2016. Palaeoclimate, environmental factors, and bird body size: A multivariable analysis of avian fossil preservation. Earth-Science Reviews 162, 177-197.

Gaston, K.J., Blackburn, T.M., Spicer, J.I., 1998. Rapoport's rule: time for an epitaph? Trends in Ecology and Evolution 13, 70-74.

Grant, R.E., 1988. The family Cardiarinidae (Late Paleozoic rhynchonellid Brachiopoda). Senckenbergiana lethaea 69, 121-135.

Greenacre, M., 2007. Correspondence Analysis in Practice, 2nd edition. Chapman \& Hall/CRC, New York.

Hammer, Ø., Harper, D.A.T., Ryan, P.D., 2001. PAST: Paleontological statistics software package for education and data analysis. Palaeontologia Electronica 4, 1-9.

Harper, E.M., Skelton, P.W., 1993. The Mesozoic Marine Revolution and epifaunal bivalves. Scripta Geologica 2, 127-153.

Harper, E.M., Peck, L.S., Hendry, K.R., 2009. Patterns of shell repair in articulate brachiopods indicate size constitutes a refuge from predation. Marine Biology 156, 1993-2000.

Harper, E.M., 2016. Uncovering the holes and cracks: from anecdote to testable hypotheses in predation studies. Palaeontology 59, 597-609.

Harper, D.A.T., Moran, R., 1997. Fossils explained 20: brachiopod life styles. Geology Today $13,235-238$. 
He, W.H., Shi, G. R., Zhang, Y., Yang, T.L., Zhang, K.X., Wu, S.B., Niu, Z.J., Zhang, Z.Y., 2014. Changhsingian (latest Permian) deep-water brachiopod fauna from South China. Journal of Systematic Palaeontology 12, 907-960.

He, W.H., Shi, G.R., Twitchett, R.J., Zhang, Y., Zhang, K.X., Song, H.J., Yue, M.L., Wu, S.B., Wu, H.T., Yang, T.L., Xiao, Y.F., 2015. Late Permian marine ecosystem collapse began in deeper waters: evidence from brachiopod diversity and body size changes. Geobiology $13,123-138$.

He, W.H., Shi, G. R., Zhang, K. X., Yang, T.L., Shen, S.Z., Zhang, Y., 2019. Brachiopods around the Permian-Triassic Boundary of South China, Changhsingian (latest Permian) deep-water brachiopod fauna from South China. Springer Nature, Singapore.

Hoffmeister, A.P., Kowalewski, M., Baumiller, T.K., Bambach, R.K., 2004. Drilling predation on Permian brachiopods and bivalves from the Glass Mountains, west Texas. Acta Palaeontologica Polonica 49, 443-454.

Jordan, D.S., 1892. Relations of temperature to vertebrae among fishes. Proceedings of the United States National Museum 1891, 107-120.

Klompmaker, A.A., Kelley, P.A., 2015. Shell ornamentation as a likely exaptation: evidence from predatory drilling on Cenozoic bivalves. Paleobiology 41, 187-201.

Klompmaker, A.A., Kelley, P.A., Chattopadhyayc, D., Clements, J.C., Huntley, J.W., Kowalewski, M., 2019. Predation in the marine fossil record: Studies, data, recognition, environmental factors, and behaviour. Earth-Science Reviews 194, 472-520.

Kowalewski, M., Dulai, A., Fursich, F.T., 1998. A fossil record full of holes: the Phanerozoic history of drilling predation. Geology 26, 1091-1094.

Kowalewski, M., Simões, M.G., Torello, F.F., Mello, L.H. C., Ghilardi, R.P., 2000. Drill holes in shells of Permian benthic invertebrates. Journal of Paleontology 74, 532-543. 
528 Kowalewski, M., Hoffmeister, A.P., Baumiller, T.K., Bambach, R.K., 2005. Secondary 529 evolutionary escalation between brachiopods and enemies of other prey. Science 308, $1774-1777$.

531

Leighton, L.R., 1999. Possible latitudinal predation gradient in middle Paleozoic oceans. Geology 27, 47-50.

Linse, K., Barnes, D.K., Enderlein, P., 2006. Body size and growth of benthic invertebrates along an Antarctic latitudinal gradient. Deep Sea Research Part II 53, 921-931.

Lomolino, M.V., Riddle, B.R., Brown, J.H. 2006. Biogeography (3rd Edition). Sinauer Associates Inc., Massachusetss, USA.

Mack, K.L., Ballinger, M.A., Phifer-Rixey, M., Nachman, M. W., 2018. Gene regulation underlies environmental adaptation in house mice. Genome research 28, 1636-1645.

Nicol, D., 1967. Some characteristics of cold-water marine pelecypods. Journal of Paleontology 41, 1330-1340.

Posenato, R., 2009. Survival patterns of macrobenthic marine assemblages during the endPermian mass extinction in the western Tethys (Dolomites, Italy). Palaeogeography, Palaeoclimatology, Palaeoecology 280, 150-167.

Posenato, R., 2011. Latest Changhsingian orthotetid brachiopods in the Dolomites (southern Alps, Italy): ecological opportunists at the peak of the end-Permian mass extinction. Journal of Paleontology 85, 58-68.

Powell, M.G., Glazier, D.S., 2017. Asymmetric geographic range expansion explains the latitudinal diversity gradients of four major taxa of marine plankton. Paleobiology 43, 196-208. 
Sanvito, S., Galimberti, F., Miller, E.H., 2007. Observational evidences of vocal learning in southern elephant seals: a longitudinal study. Ethology 113, 137-146.

Schemske, D.W., Mittelbach, G.G., Cornell, H.V., Sobel, J.M., Roy, K., 2009. Is there a latitudinal gradient in the importance of biotic interactions? Annual Review of Ecology, Evolution, and Systematics 40, 245-269.

Scotese, C.R., 2001. Paleomap project. http://www.scotese.com/ (accessed 24 March 2014).

Scotese, C.R., 2004. PointTracker v. 04c. PALEOMAP Project, Arlington, Texas.

Shen, S.Z., Shi, G.R., 2007. Lopingian (Late Permian) brachiopods from South China, Part 1: Orthotetida, Orthida and Rhynchonellida. Bulletin of the Tohoku University Museum 6, $1-102$.

Shen, S.Z., Archbold, N.W., Shi, G.R., 2001. Changhsingian (Late Permian) brachiopod palaeobiogeography. Historical Biology 15, 121-134.

Shi, G.R., Zhang, Y.C., Shen, S.Z., He, W.H., 2016. Nearshore-offshore-basin species diversity and body size variation patterns in Late Permian (Changhsingian) brachiopods. Palaeogeography, Palaeoclimatology, Palaeoecolog 448, 96-107.

Signor, P.W., Brett, C.E., 1984. The mid-Paleozoic precursor to the Mesozoic marine revolution. Paleobiology 10, 229-245.

Stanley, S.M., 1970. Relation of shell form to life habits of the Bivalvia (Mollusca). Geological Society of America Memoir 125, 1-296.

Stone, H.M.I., 1998. On predator deterrence by pronounced shell ornament in epifaunal bivalves. Palaeontology 41, 1051-1068. 
571 Trussell, G.C., 2000. Phenotypic clines, plasticity, and morphological trade-offs in an intertidal snail. Evolution 54, 151-166.

Veter, N.M., DeSantis, L.R., Yann, L.T., Donohue, S.L., Haupt, R.J., Corapi, S. E., Fathel, S.L., Gootee, E.K., Loffredo, L.F., Romer, J.L., Velkovsky, S.M., 2013. Is Rapoport's rule a recent phenomenon? A deep time perspective on potential causal mechanisms. Biology Letters 9, 20130398.

Vermeij, G.J., 1977. The Mesozoic faunal revolution: evidence from snails, predators and grazers. Paleobiology 3, 245-258.

Vermeij, G.J., 1978. Biogeography and Adaptation. Harvard University Press, Cambridge, Massachusetts, USA.

Vermeij, G.J., 1987. Evolution and escalation: an ecological history of life. Princeton University Press, Princeton, New Jersey.

Vörös, A., 2010. Escalation reflected in ornamentation and diversity history of brachiopod clades during the Mesozoic marine revolution. Palaeogeography, Palaeoclimatology, Palaeoecology 291, 474-480.

Vörös, A., 2014. Latitudinal variation of brachiopod ornamentation in the Jurassic faunas from the western Tethys and its possible relation to a predation gradient. Palaeogeography, Palaeoclimatology, Palaeoecology 403, 57-65.

Watson, S.A., 2009. Latitudinal gradients in marine invertebrate shell morphology: production costs and predation pressure. Unpublished $\mathrm{PhD}$ thesis, University of Southampton, National Oceanographic Library, UK.

Watson, S.A., Peck, L.S., Tyler, P.A., Southgate, P.C., Tan, K.S., Day, R.W., Morley, S.A., 2012. Marine invertebrate skeleton size varies with latitude, temperature and carbonate 
saturation: implications for global change and ocean acidification. Global Change Biology $18,3026-3038$.

Williams, A. \& 17 others, 2000. Linguliformea, Craniiformea, and Rhynchonelliformea (part), in: Williams, A., Brunton, C.H.C., Carlson, S.J. and 44 others (Eds.), Treatise on invertebrate paleontology, part H, Brachiopoda, Revised Volume $2 \& 3$. The University of Kansas, Lawrence, pp. 1-919.

Williams, A. \& 15 others, 2002. Rhynchonelliformea (part), in: Williams, A., Brunton, C.H.C., Carlson, S.J. and 45 others (Eds.), Treatise on invertebrate paleontology, part H, Brachiopoda, Revised Volume 4. The University of Kansas, Lawrence, pp. 920-1688.

Williams, A. \& 15 others, 2006. Rhynchonelliformea (part), in: Williams, A., Brunton, C.H.C., Carlson, S.J. and 45 others (Eds.), Treatise on invertebrate paleontology, part H, Brachiopoda, Revised Volume 5. The University of Kansas, Lawrence, pp. 1688-2320.

Williams, A. \& 28 others, 2007. Supplement, in: Williams, A., Brunton, C.H.C., Carlson, S.J. and 45 others (Eds.), Treatise on invertebrate paleontology, part H, Brachiopoda, Revised Volume 6. The University of Kansas, Lawrence, pp. 2321-3226.

Willig, M.R., Kaufman, D.M., Stevens, R.D., 2003. Latitudinal gradients of biodiversity: Pattern, Process, Scale, and Synthesis. Annual review of ecology, evolution, and systematics $34,273-309$.

Wu, H.T., He, W.H., Shi, G.R., Zhang, K.X., Yang, T.L., Zhang, Y., Xiao, Y.F., Chen, B., Wu, S.B., 2018a. A new Permian-Triassic boundary brachiopod fauna from the Xinmin section, southwestern Guizhou, south China and its extinction patterns. Alcheringa 42, 339-372. 
Wu, H.T., He, W.H., Weldon, E.A., 2018b. Prelude of benthic community collapse during the end-Permian mass extinction in siliciclastic offshore sub-basin: Brachiopod evidence from South China. Global and Planetary Change 163, 158-170.

Zhang, Y., He, W.H., 2008. Evolutionary patterns of Productida (Brachiopoda) morphology during the Permian in South China. Science in China Series D: Earth Sciences 51, 15891600.

Zhang, Y., He, W.H., Shi, G.R., Zhang, K.X., 2013. A new Changhsingian (Late Permian) Rugosochonetidae (Brachiopoda) fauna from the Zhongzhai section, southwestern Guizhou Province, South China. Alcheringa 37, 223-247.

Zhang, Y., Shi, G.R., He, W.H., Zhang, K.X., Wu, H.T., 2014. A new Changhsingian (Late Permian) brachiopod fauna from the Zhongzhai section (South China), Part 2: Lingulida, Orthida, Orthotetida and Spiriferida. Alcheringa 38, 480-503.

Zhang, Y., He, W.H., Shi, G.R., Zhang, K.X., Wu, H.T., 2015. A new Changhsingian (Late Permian) brachiopod fauna from the Zhongzhai section (South China) Part 3: Productida. Alcheringa 39, 295-314.

Zhang, Y., Shi, G.R., He, W.H., Wu, H.T., Lei, Y., Zhang, K.X., Du, C.C., Yang, T.L., Yue, M.L., Xiao, Y.F., 2016. Significant pre-mass extinction animal body-size changes: evidences from the Permian-Triassic boundary brachiopod faunas of South China. Palaeogeography, Palaeoclimatology, Palaeoecology 448, 85-95.

Zuschin, M., Stachowitsch, M., Stanton Jr., R.J., 2003. Patterns and processes of shell fragmentation in modern and ancient marine environments. Earth-Science Reviews 63, 33-82. 


\section{Caption}

642 Figure 1. Paleogeographic distribution of Changhsingian brachiopods, paleomap modified 643 from Scotese (2001).

Figure 2. Ornament combination types and corresponding examples of brachiopods and sketches. 1. Costatumulus from He et al. (2014); 2. Paryphella from Zhang et al. (2015); 3. Transennatia from Williams et al. (2000); 4. Fusichonetes from Zhang et al. (2013); 5. Licharewiella from Williams et al. (2000); 6. Spinomarginifera from Williams et al. (2000); 7. Huatangia from Williams et al. (2000); 8. Quinquenella from Williams et al. (2000); 9. Strophalosia from Williams et al. (2000); 10. Spiriferella from Williams et al. (2006); 11. Crurithyris from Williams et al. (2006).

652

Figure 3. OCI (ornament complexity index) expressed as relative frequencies of occurrences of specimens across paleolatitudinal areas of the southern hemisphere and its changing trend. Note the distinct linear latitudinal gradient tested by the Cochran-Armitage trend statistic. Full explanation of OCI is given in Table 2.

657

Figure 4. ROI (radial ornament index) expressed as relative frequencies of occurrences of 659 specimens across paleolatitudinal areas of the southern hemisphere and its changing trend. Note 660 the distinct linear latitudinal gradient tested by the Cochran-Armitage trend statistic. Full explanation of ROI is given in Table 2. 
Figure 5. BSI (body spine index) expressed as relative frequencies of occurrences of specimens

664

665

666

667

668

669

670

671

672

673

674

675

676

677

678

679

680

681

682

683

684

685

686

across paleolatitudinal areas of the southern hemisphere and its changing trend. Note the distinct linear latitudinal gradient tested by the Cochran-Armitage trend statistic. Full explanation of BSI is given in Table 2.

Figure 6. Box plot of COI (composite ornament index) changes along paleolatitude in the Changhsingian. Circles represent outliers; upward arrows indicate significant changes (MannWhitney $\mathrm{U}$ test, $p<0.05$ ) between adjacent paleolatitudinal bins.

Figure 7. Biplot of correspondence analysis (CA) of 20-degree paleolatitudinal bins and COI values (green numbers). See text for more explanation.

Figure 8. Biplot of correspondence analysis (CA) of 10-degree paleolatitudinal bins and COI values (green numbers). See text for more explanation.

Figure 9. Linear regression of paleolatitudinal bins (using the mean paleolatitude value in each paleolatitudinal bin as the centroid for each pie diagram) to chi-square distance between each profile and mean profile. The COI profile of each paleolatitudinal bin is shown as a pie chart.

Table 1. Definitions of four types of Changhsingian ornaments and their measurement methods.

Table 2. Definitions and mathematical formulae of the ornament metrics used in this paper to quantify and estimate the relative degree of brachiopod ornament strength within a paleolatitudinal bin during the Changhsingian. 
688 Table 3. Chi-square distances to the origin, showing the dissimilarity between the category 689 profile and the mean profile of ornament composition.

690

691 Table 4. Chi-square distances between category profiles, giving information about the 692 dissimilarity of ornament composition between each category. Bold numbers are distances of 693 every pair of the nearest paleolatitudinal bins, numbers written in italics are outliers.

694 


\section{Caption}

2

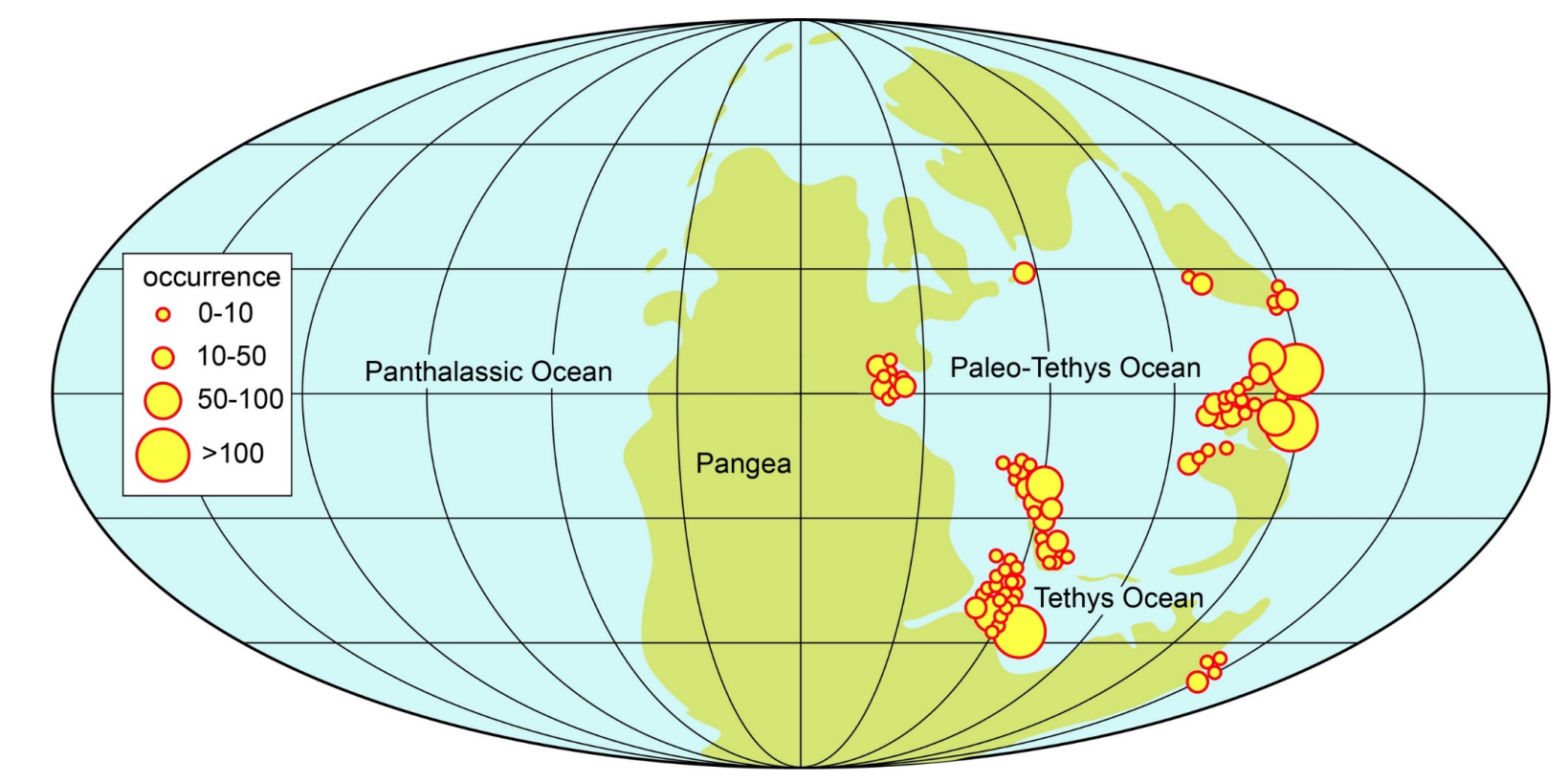

4 Figure 1. Paleogeographic distribution of Changhsingian brachiopods, paleomap modified

5 from Scotese (2001). 


\begin{tabular}{|c|c|c|}
\hline $\begin{array}{c}\text { Ornament } \\
\text { combination type }\end{array}$ & $\begin{array}{l}\text { Examples of } \\
\text { brachiopod }\end{array}$ & $\begin{array}{c}\text { Sketch of } \\
\text { ornament type }\end{array}$ \\
\hline $\begin{array}{c}\text { Hinge spine+ } \\
\text { body spine+ } \\
\text { costa+ruga }\end{array}$ & & \\
\hline $\begin{array}{l}\text { Hinge spine+ } \\
\text { costa+ruga }\end{array}$ & & \\
\hline $\begin{array}{c}\text { Body spine+ } \\
\text { costa+ruga }\end{array}$ & $2 \mathrm{~mm}$ & \\
\hline $\begin{array}{l}\text { Hinge spine+ } \\
\text { costa }\end{array}$ & & \\
\hline Body spine + costa & & \\
\hline Body spine+ruga & & \\
\hline Costa+ruga & $\begin{array}{r}7 \\
2 \mathrm{~mm}\end{array}$ & \\
\hline Hinge spine & & \\
\hline Body spine & $5 \mathrm{~mm}$ & \\
\hline Costa & & \\
\hline smooth shell & & \\
\hline
\end{tabular}

8 Figure 2. Ornament combination types and corresponding examples of brachiopods and

9 sketches. 1. Costatumulus from He et al. (2014); 2. Paryphella from Zhang et al. (2015); 3.

10 Transennatia from Williams et al. (2000); 4. Fusichonetes from Zhang et al. (2013); 5.

11 Licharewiella from Williams et al. (2000); 6. Spinomarginifera from Williams et al. (2000); 7.

12 Huatangia from Williams et al. (2000); 8. Quinquenella from Williams et al. (2000); 9.

13 Strophalosia from Williams et al. (2000); 10. Spiriferella from Williams et al. (2006); 11.

14 Crurithyris from Williams et al. (2006). 


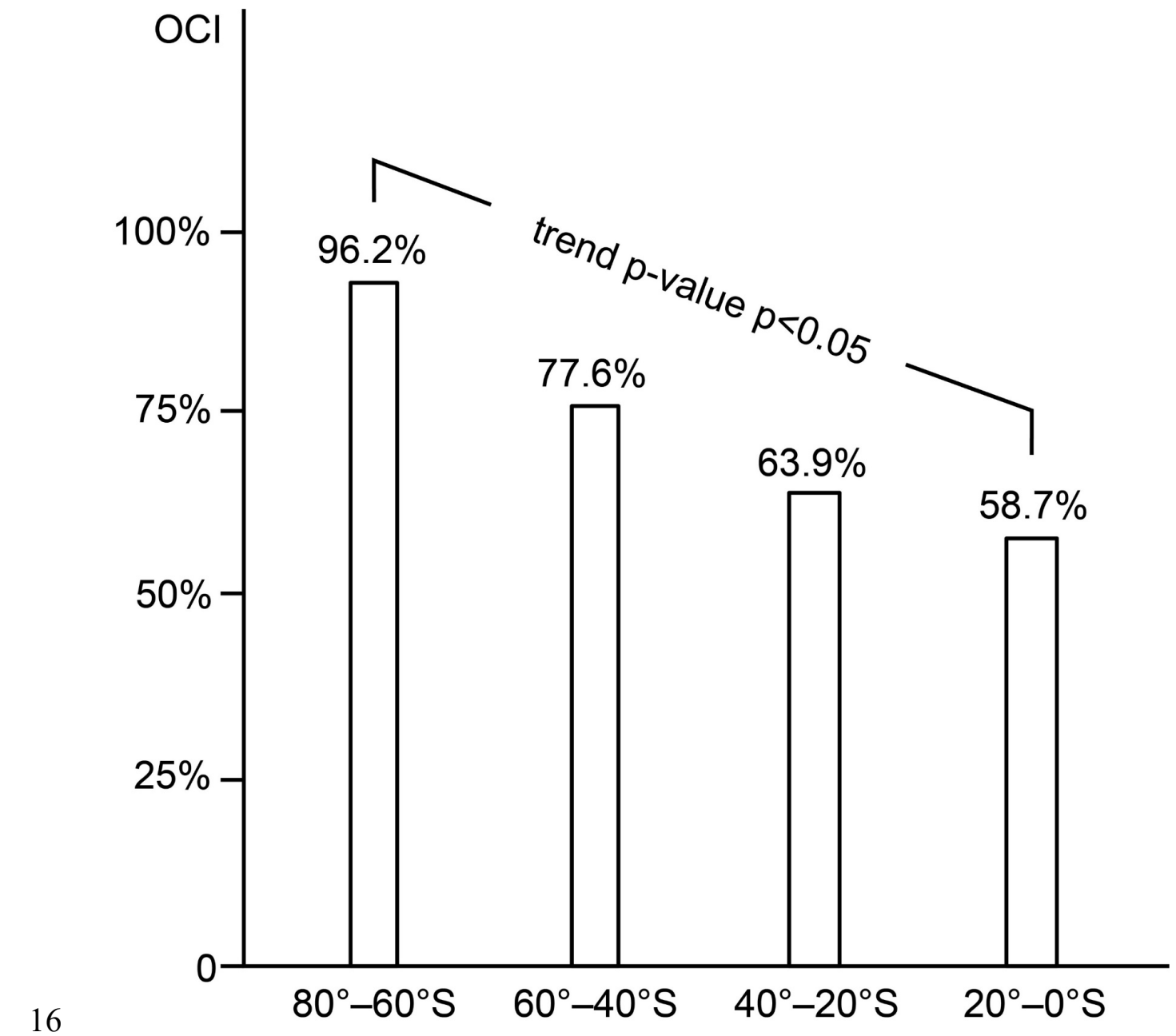

17 Figure 3. OCI (ornament complexity index) expressed as relative frequencies of occurrences

18 of specimens across paleolatitudinal areas of the southern hemisphere and its changing trend.

19 Note the distinct linear latitudinal gradient trend tested by the Cochran-Armitage trend statistic.

20 Full explanation of OCI is given in Table 2. (Note that Changhsingian brachiopods in northern

21 hemisphere fell into only two latitudinal bins, insufficient for a Cochran-Armitage trend test, hence no northern hemisphere data could be shown here; same reason for ROI and BSI analyses in Figs. 4, 5) 


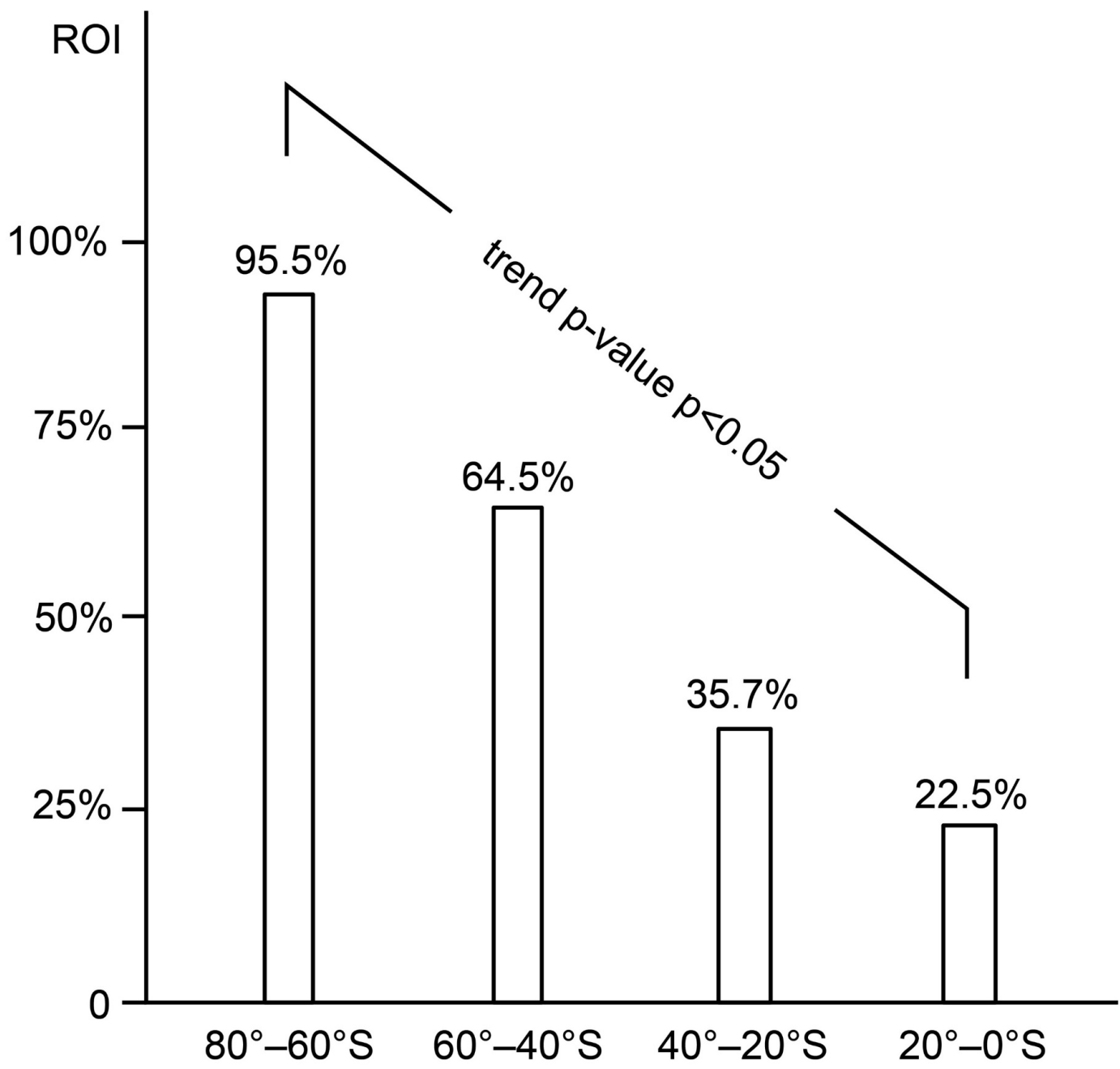

28 Figure 4. ROI (radial ornament index) expressed as relative frequencies of occurrences of

29 specimens across paleolatitudinal areas of the southern hemisphere and its changing trend. Note

30 the distinct linear latitudinal gradient trend tested by the Cochran-Armitage trend statistic. Full

31 explanation of ROI is given in Table 2. 


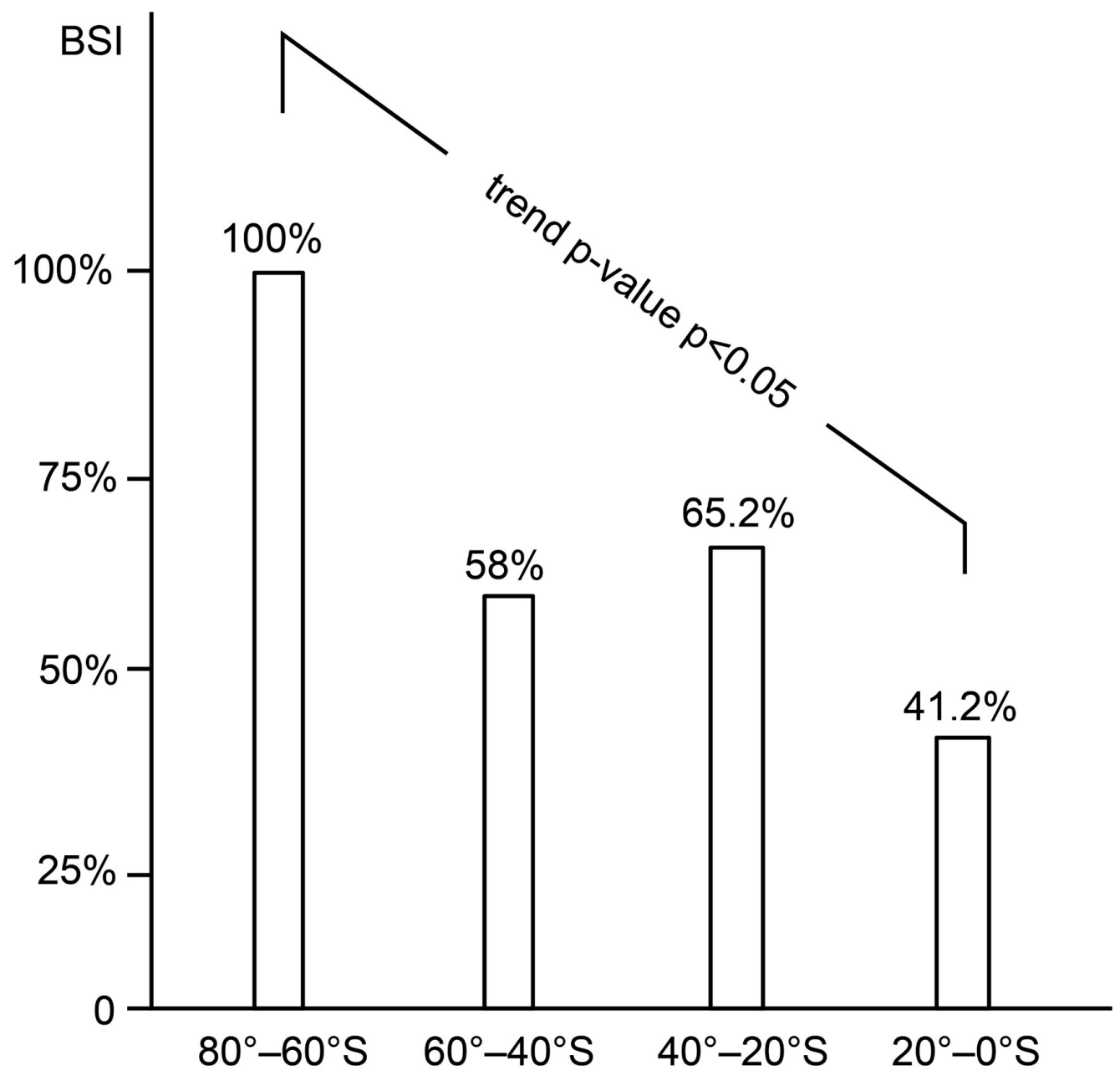

38 Figure 5. BSI (body spine index) expressed as relative frequencies of occurrences of specimens across paleolatitudinal areas of the southern hemisphere and its changing trend. Note the distinct linear latitudinal gradient trend tested by the Cochran-Armitage trend statistic. Full

41 explanation of ROI is given in Table 2.

42 


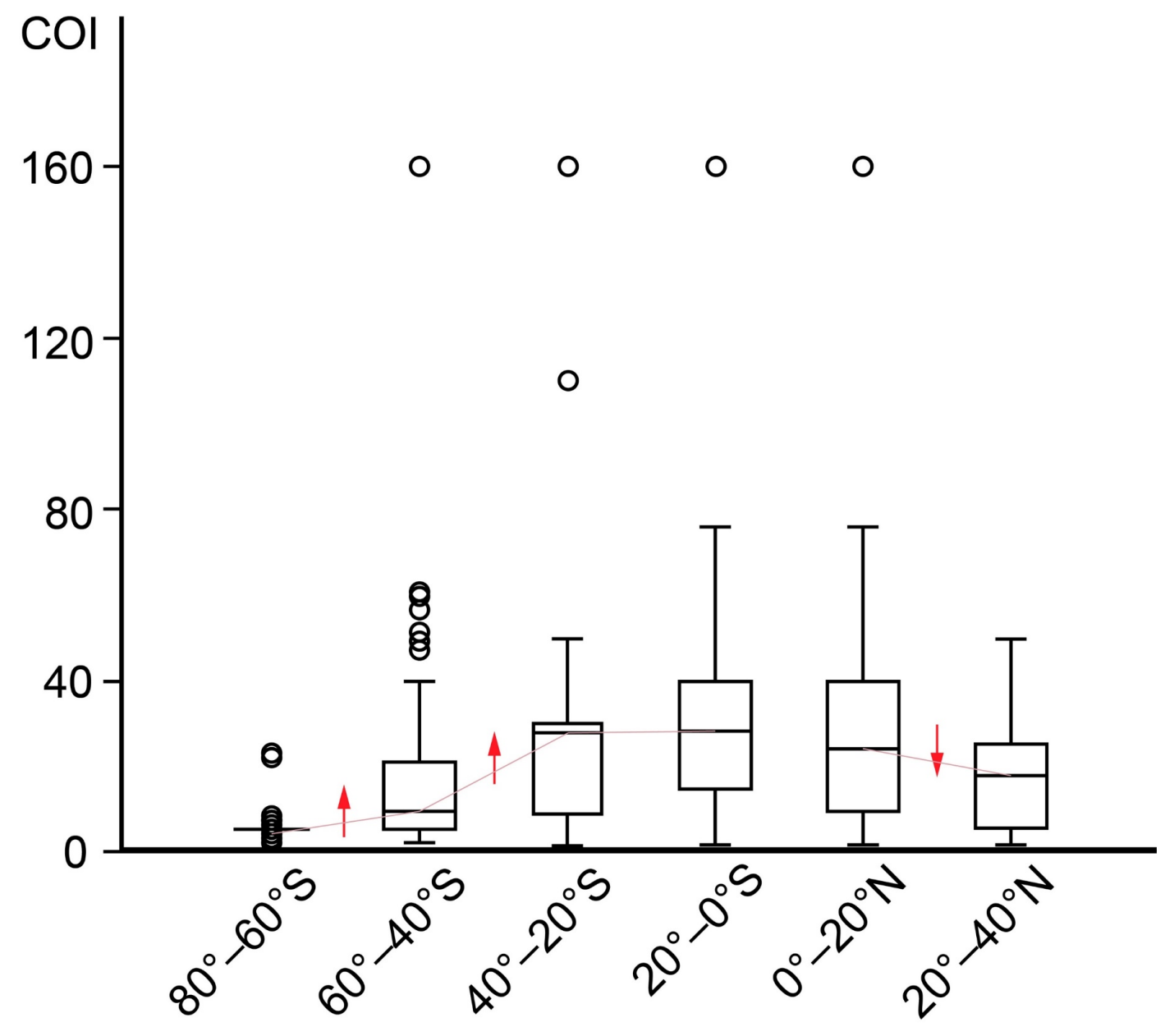

48 Figure 6. Box plot of COI (composite ornament index) changes along paleolatitudes in the

49 Changhsingian. Circles represent outliers; upward arrows indicate significant changes (Mann-

50 Whitney $\mathrm{U}$ test, $p<0.05$ ) between adjacent paleolatitudinal bins. 


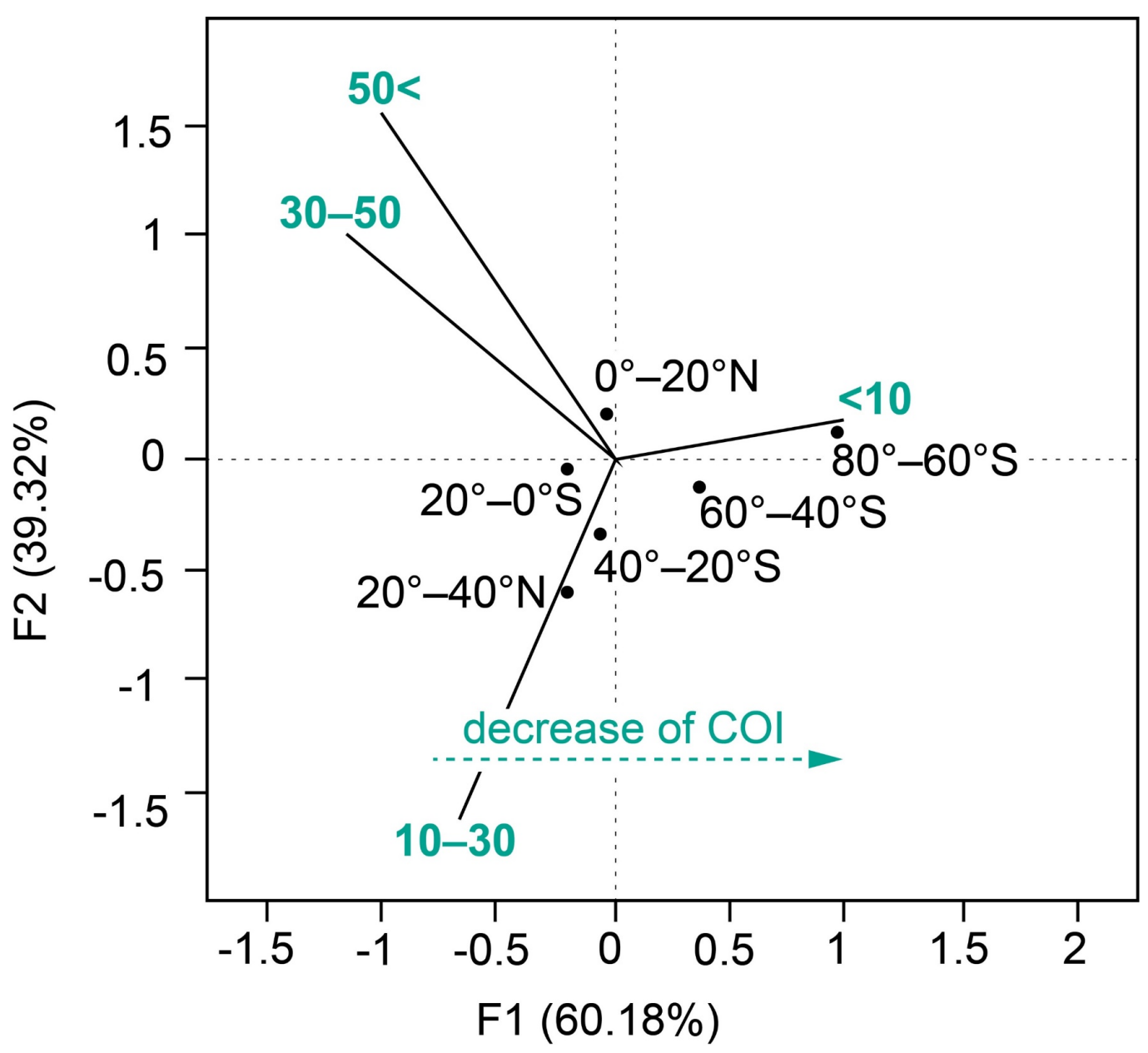

58 Figure 7. Biplot of correspondence analysis (CA) of 20-degree paleolatitudinal bins and COI

59 values (light green numbers). See text for more explanation.

60

61

62

63

64

65

66 


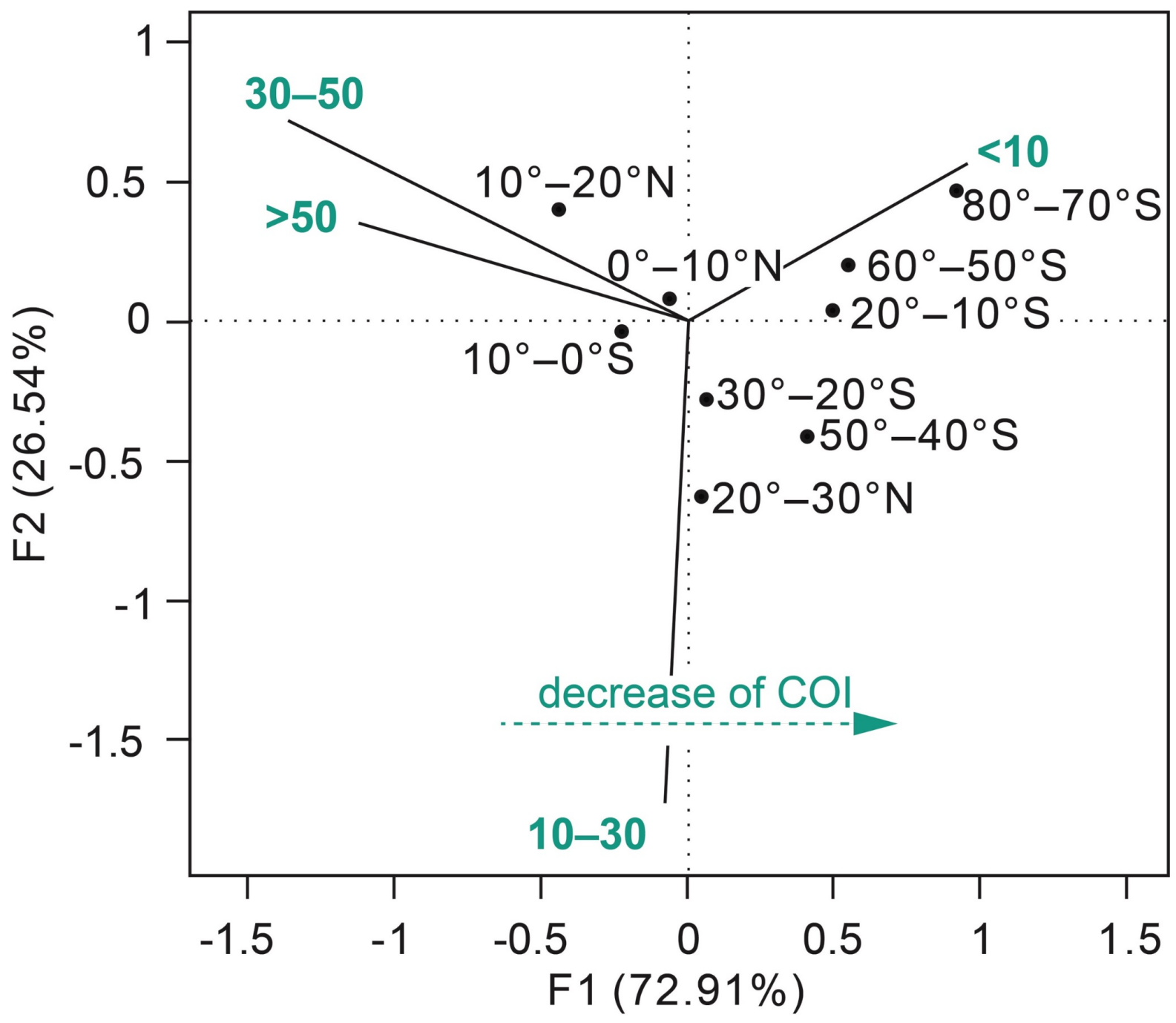

68 


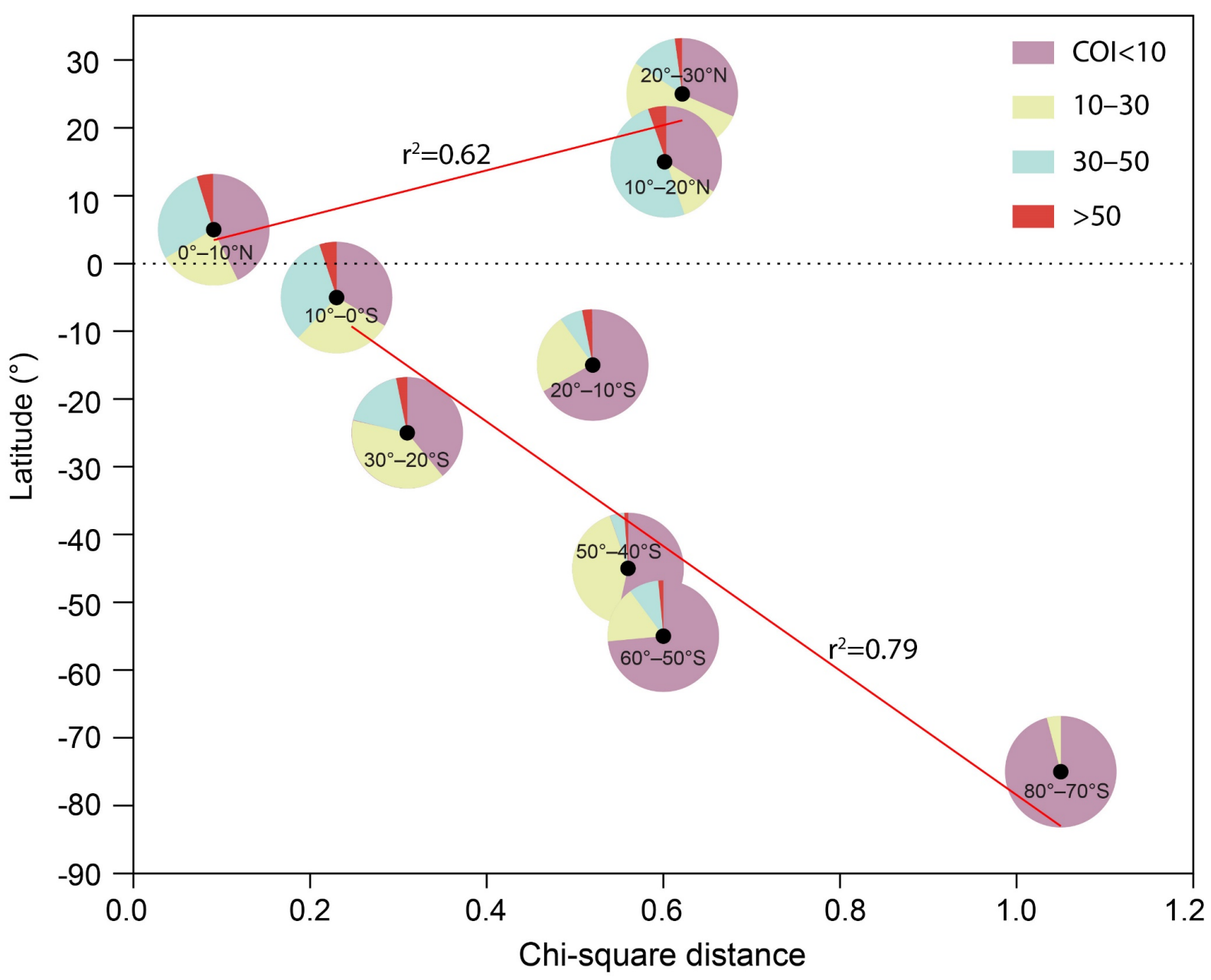

Figure 9. Linear regression of paleolatitudinal bins (using the mean paleolatitude value in each paleolatitudinal bin as the centroid for each pie diagram) to Chi-square distance between each

79 profile and mean profile. The COI profile of each paleolatitudinal bin is shown as a pie chart. 


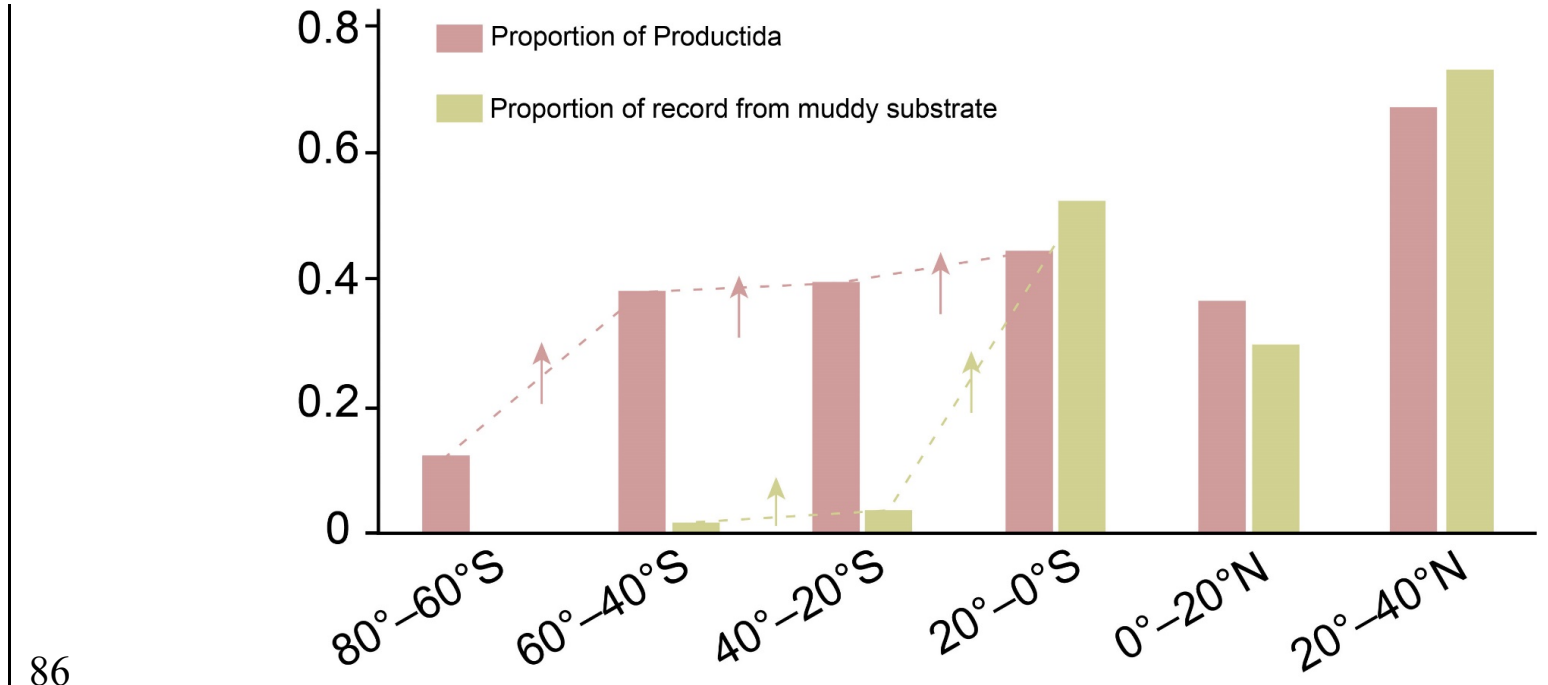

87 Figure 10. Histogram of proportion of Productida and record from muddy substrate in different

88 tatitude areas.

89 


\begin{tabular}{|l|l|l|}
\hline $\begin{array}{l}\text { Four types of } \\
\text { ornament }\end{array}$ & Definition & Frequency measurement \\
\hline Hinge spines & Spines located along the hingeline & Number of hinge spines in $1 \mathrm{~cm}$ \\
\hline Body spines & $\begin{array}{l}\text { Macro spines dispersed on the external } \\
\text { surface of the shell, but excluding hingeline }\end{array}$ & Number of hinge spines in $1 \mathrm{~cm}$ \\
\hline Costa & $\begin{array}{l}\text { Radial ornamentation distributed on external } \\
\text { shell surface }\end{array}$ & Number of costae across $1 \mathrm{~cm}$ \\
\hline Ruga & $\begin{array}{l}\text { Concentric ornamentation on shell external } \\
\text { surface }\end{array}$ & Number of rugae across $1 \mathrm{~cm}$ \\
\hline
\end{tabular}

Table 1. Definitions of four types of Changhsingian ornaments and their measurement methods. 


\begin{tabular}{|c|c|c|c|}
\hline Name of ornament metric & Abbreviation & Definition & $\begin{array}{l}\text { Mathematical } \\
\text { formula }\end{array}$ \\
\hline Ornament complexity index & $\mathrm{OCl}$ & $\begin{array}{l}\text { Percent of number of specimens with no ornament or only } \\
\text { one type of ornament }\left(\mathbf{N}_{1}\right) \text { to number of specimens with } \\
\text { more than one type of ornament }\left(\mathbf{N}_{2}\right)\end{array}$ & $\mathrm{OCl}=\mathrm{N}_{1} / \mathrm{N}_{2} * 100 \%$ \\
\hline Radial ornament index & $\mathrm{ROI}$ & $\begin{array}{l}\text { Percent of number of specimens with radial ornament } \\
\text { frequency equal to or less than } 10 / \mathrm{cm}\left(\mathbf{N}_{3}\right) \text { to the number } \\
\text { of specimens with radial ornament frequency more than } \\
\qquad 10 / \mathrm{cm}\left(\mathbf{N}_{4}\right)\end{array}$ & $\mathrm{ROI}=\mathrm{N}_{3} / \mathrm{N}_{4}{ }^{*} 100 \%$ \\
\hline Body spine index & $\mathrm{BSI}$ & $\begin{array}{l}\text { Percent of number of specimens with body spine } \\
\text { frequency equal to or less than } 8 / \mathrm{cm}\left(\mathrm{N}_{5}\right) \text { to number of } \\
\text { specimens with body spine frequency more than } 8 / \mathrm{cm}\left(\mathrm{N}_{6}\right)\end{array}$ & $\mathrm{BSI}=\mathrm{N}_{5} / \mathrm{N}_{6}{ }^{*} 100 \%$ \\
\hline Composite ornament index & $\mathrm{COI}$ & $\begin{array}{l}\text { Sum of hinge spine frequency }\left(\mathbf{F}_{1}\right) \text {, body spine frequency } \\
\left(\mathbf{F}_{2}\right) \text {, radial ornament frequency }\left(\mathbf{F}_{3}\right) \text { and ruga frequency } \\
\qquad\left(\mathbf{F}_{\mathbf{4}}\right)\end{array}$ & $\mathrm{COI}=\mathrm{F}_{1}+\mathrm{F}_{2}+\mathrm{F}_{3}+\mathrm{F}_{4}$ \\
\hline
\end{tabular}




\begin{tabular}{|c|c|}
\hline & $\begin{array}{c}\text { Distance between profile of each } \\
\text { latitudinal bin and mean profile }\end{array}$ \\
\hline $80^{\circ}-70^{\circ} \mathrm{S}$ & 1.05 \\
\hline $60^{\circ}-50^{\circ} \mathrm{S}$ & 0.6 \\
\hline $50^{\circ}-40^{\circ} \mathrm{S}$ & 0.56 \\
\hline $30^{\circ}-20^{\circ} \mathrm{S}$ & 0.31 \\
\hline $20^{\circ}-10^{\circ} \mathrm{S}$ & 0.52 \\
\hline $10^{\circ}-0^{\circ} \mathrm{S}$ & 0.23 \\
\hline $0^{\circ}-10^{\circ} \mathrm{N}$ & 0.09 \\
\hline $10^{\circ}-20^{\circ} \mathrm{N}$ & 0.6 \\
\hline $20^{\circ}-30^{\circ} \mathrm{N}$ & 0.62 \\
\hline
\end{tabular}

100

101 Table 3. Chi-square distances to the origin, showing the dissimilarity between the category

102 profile and the mean profile of ornament composition.

103

104

105

106 


\begin{tabular}{|c|c|c|c|c|c|c|c|c|c|}
\hline & $80^{\circ}-70^{\circ} \mathrm{S}$ & $60^{\circ}-50^{\circ} \mathrm{S}$ & $50^{\circ}-40^{\circ} \mathrm{S}$ & $30^{\circ}-20^{\circ} \mathrm{S}$ & $20^{\circ}-10^{\circ} \mathrm{S}$ & $10^{\circ}-0^{\circ} \mathrm{S}$ & $0^{\circ}-10^{\circ} \mathrm{N}$ & $10^{\circ}-20^{\circ} \mathrm{N}$ & $20^{\circ}-30^{\circ} \mathrm{N}$ \\
\hline $80^{\circ}-70^{\circ} \mathrm{S}$ & 0 & 0.462 & 0.979 & 1.169 & 0.61 & 1.271 & 1.087 & 1.396 & 1.398 \\
\hline $60^{\circ}-50^{\circ} \mathrm{S}$ & $\mathbf{0 . 4 6 2}$ & 0 & 0.581 & 0.712 & 0.195 & 0.824 & 0.648 & 1.033 & 0.96 \\
\hline $50^{\circ}-40^{\circ} \mathrm{S}$ & 0.979 & $\mathbf{0 . 5 8 1}$ & 0 & 0.366 & 0.419 & 0.714 & 0.645 & 1.153 & 0.448 \\
\hline $30^{\circ}-20^{\circ} \mathrm{S}$ & 1.169 & 0.712 & $\mathbf{0 . 3 6 6}$ & 0 & 0.568 & 0.378 & 0.383 & 0.865 & 0.311 \\
\hline $20^{\circ}-10^{\circ} \mathrm{S}$ & 0.61 & 0.195 & 0.419 & $\mathbf{0 . 5 6 8}$ & 0 & 0.74 & 0.579 & 1.033 & 0.804 \\
\hline $10^{\circ}-0^{\circ} \mathrm{S}$ & 1.271 & 0.824 & 0.714 & 0.378 & 0.74 & 0 & 0.189 & 0.502 & 0.622 \\
\hline $0^{\circ}-10^{\circ} \mathrm{N}$ & 1.087 & 0.648 & 0.645 & 0.383 & 0.579 & 0.189 & 0 & 0.516 & 0.68 \\
\hline $10^{\circ}-20^{\circ} \mathrm{N}$ & 1.396 & 1.033 & 1.153 & 0.865 & 1.033 & 0.502 & 0.516 & 0 & $\mathbf{1 . 1 1 7}$ \\
\hline $20^{\circ}-30^{\circ} \mathrm{N}$ & 1.398 & 0.96 & 0.448 & 0.311 & 0.804 & 0.622 & 0.68 & 1.117 & 0 \\
\hline
\end{tabular}

108

109

110 Table 4. Chi-square distances between category profiles, giving information about the dissimilarity of ornament composition between each

111 category. Bold numbers are distances of every pair of the nearest paleolatitudinal bins, numbers written in italics are outliers. 
113 Supplementary data:

114 Data for analyzing OCI changes

\begin{tabular}{|c|c|c|}
\hline $\begin{array}{c}\text { Paleolatitude } \\
\text { bins }\end{array}$ & $\begin{array}{c}\text { Number of specimens with no } \\
\text { or only one type of ornament }\end{array}$ & $\begin{array}{c}\text { Number of specimens with more } \\
\text { than one type of ornament }\end{array}$ \\
\hline $80^{\circ}-60^{\circ} \mathrm{S}$ & 25 & 1 \\
\hline $60^{\circ}-40^{\circ} \mathrm{S}$ & 301 & 87 \\
\hline $40^{\circ}-20^{\circ} \mathrm{S}$ & 39 & 22 \\
\hline $20^{\circ}-0^{\circ} \mathrm{S}$ & 582 & 409 \\
\hline $0^{\circ}-20^{\circ} \mathrm{N}$ & 728 & 398 \\
\hline $20^{\circ}-40^{\circ} \mathrm{N}$ & 18 & 30 \\
\hline
\end{tabular}

115

116 Data for analyzing ROI changes

\begin{tabular}{|c|c|c|}
\hline $\begin{array}{c}\text { Paleolatitude } \\
\text { bins }\end{array}$ & $\begin{array}{c}\text { Number of specimens with radial ornament } \\
\text { frequency equal to or less than 10/cm }\end{array}$ & $\begin{array}{c}\text { Number of specimen with radial } \\
\text { ornament frequency more than 10/cm }\end{array}$ \\
\hline $80^{\circ}-60^{\circ} \mathrm{S}$ & 21 & 1 \\
\hline $60^{\circ}-40^{\circ} \mathrm{S}$ & 147 & 81 \\
\hline $40^{\circ}-20^{\circ} \mathrm{S}$ & 15 & 27 \\
\hline $20^{\circ}-0^{\circ} \mathrm{S}$ & 145 & 500 \\
\hline $0^{\circ}-20^{\circ} \mathrm{N}$ & 285 & 539 \\
\hline $20^{\circ}-40^{\circ} \mathrm{N}$ & 22 & 23 \\
\hline
\end{tabular}

117 
Data for analyzing BSI changes

\begin{tabular}{|c|c|c|}
\hline $\begin{array}{c}\text { Paleolatitude } \\
\text { bins }\end{array}$ & $\begin{array}{c}\text { Number of specimens with body spine } \\
\text { frequency equal to or less than 8/cm }\end{array}$ & $\begin{array}{c}\text { Number of specimen with body } \\
\text { spine frequency more than 8/cm }\end{array}$ \\
\hline $80^{\circ}-60^{\circ} \mathrm{S}$ & 2 & 0 \\
\hline $60^{\circ}-40^{\circ} \mathrm{S}$ & 76 & 55 \\
\hline $40^{\circ}-20^{\circ} \mathrm{S}$ & 15 & 8 \\
\hline $20^{\circ}-0^{\circ} \mathrm{S}$ & 82 & 117 \\
\hline $0^{\circ}-20^{\circ} \mathrm{N}$ & 40 & 51 \\
\hline $20^{\circ}-40^{\circ} \mathrm{N}$ & 16 & 11 \\
\hline
\end{tabular}

120

121 


\begin{tabular}{|c|c|c|c|c|}
\hline $\begin{array}{c}\text { Paleolatitude } \\
\text { bins }\end{array}$ & $\begin{array}{c}\text { Category 1: specimen } \\
\text { number of brachiopod } \\
\text { with COI less than 10 }\end{array}$ & $\begin{array}{c}\text { Category 2: specimen number } \\
\text { of brachiopod with COI ranging } \\
\text { between 10 and 30 }\end{array}$ & $\begin{array}{c}\text { Category 3: specimen number } \\
\text { of brachiopod with COI ranging } \\
\text { between 31 and 50 }\end{array}$ & $\begin{array}{c}\text { Category 4: specimen } \\
\text { number of brachiopod } \\
\text { with COI more than 50 }\end{array}$ \\
\hline $80^{\circ}-60^{\circ} \mathrm{S}$ & 25 & 1 & 0 & 0 \\
\hline $60^{\circ}-40^{\circ} \mathrm{S}$ & 254 & 90 & 40 & 4 \\
\hline $40^{\circ}-20^{\circ} \mathrm{S}$ & 25 & 24 & 296 & 2 \\
\hline $20^{\circ}-0^{\circ} \mathrm{S}$ & 374 & 291 & 351 & 30 \\
\hline $0^{\circ}-20^{\circ} \mathrm{N}$ & 545 & 187 & 9 & 43 \\
\hline $20^{\circ}-40^{\circ} \mathrm{N}$ & 17 & 26 & & 0 \\
\hline
\end{tabular}

\begin{tabular}{|c|c|c|c|c|}
\hline $\begin{array}{c}\text { Paleolatitude } \\
\text { bins }\end{array}$ & $\begin{array}{c}\text { Category 1: specimen } \\
\text { number of brachiopod } \\
\text { with COI less than 10 }\end{array}$ & $\begin{array}{c}\text { Category 2: specimen number } \\
\text { of brachiopod with COI } \\
\text { ranging between 10 and 30 }\end{array}$ & $\begin{array}{c}\text { Category 3: specimen number } \\
\text { of brachiopod with COI ranging } \\
\text { between 31 and 50 }\end{array}$ & $\begin{array}{c}\text { Category 4: specimen } \\
\text { number of brachiopod } \\
\text { with COI more than 50 }\end{array}$ \\
\hline $80^{\circ}-70^{\circ} \mathrm{S}$ & 25 & 1 & 0 & 0 \\
\hline $60^{\circ}-50^{\circ} \mathrm{S}$ & 157 & 35 & 20 & 2 \\
\hline $50^{\circ}-40^{\circ} \mathrm{S}$ & 92 & 71 & 11 & 2 \\
\hline $30^{\circ}-20^{\circ} \mathrm{S}$ & 24 & 24 & 10 & 2 \\
\hline $20^{\circ}-10^{\circ} \mathrm{S}$ & 98 & 34 & 276 & 4 \\
\hline $10^{\circ}-0^{\circ} \mathrm{S}$ & 279 & 242 & 297 & 41 \\
\hline $0^{\circ}-10^{\circ} \mathrm{N}$ & 436 & 243 & 49 & \\
\hline $10^{\circ}-20^{\circ} \mathrm{N}$ & 33 & 10 & 7 & 47 \\
\hline $20^{\circ}-30^{\circ} \mathrm{N}$ & 16 & 27 & & 5 \\
\hline
\end{tabular}


Database of Permian brachiopod predation record

\begin{tabular}{|c|c|c|c|c|c|c|c|}
\hline Species name & Geographic area & Age & $\begin{array}{l}\text { Palaeo- } \\
\text { latitude }\end{array}$ & Data source & $\begin{array}{l}\text { Numbers } \\
\text { of holes }\end{array}$ & $\begin{array}{l}\text { hole size } \\
(\mathrm{mm})\end{array}$ & References \\
\hline $\begin{array}{l}\text { Athyris pectinifera } \\
\text { (Spiriferida) }\end{array}$ & $\begin{array}{l}\text { Kirillow, Novgorod } \\
\text { region, Russia }\end{array}$ & Permian & $\sim 40$ & $\begin{array}{l}\text { Yakovlev, } \\
1926\end{array}$ & 1 & ? & Kowalewski et al., 2000 \\
\hline $\begin{array}{l}\text { Athyris pectinifera } \\
\text { (Spiriferida) }\end{array}$ & $\begin{array}{l}\text { Kirillow, Novgorod } \\
\text { region, Russia }\end{array}$ & Permian & $\sim 40$ & $\begin{array}{l}\text { Yakovlev, } \\
1926\end{array}$ & 1 & ? & Kowalewski et al., 2000 \\
\hline $\begin{array}{l}\text { Camarophoria superstes } \\
\text { (Rhynchonellida) }\end{array}$ & $\begin{array}{l}\text { Kirillow, Novgorod } \\
\text { region, Russia }\end{array}$ & Permian & $\sim 40$ & $\begin{array}{l}\text { Yakovlev, } \\
1926\end{array}$ & 1 & ? & Kowalewski et al., 2000 \\
\hline $\begin{array}{l}\text { Camarophoria superstes } \\
\text { (Rhynchonellida) }\end{array}$ & $\begin{array}{l}\text { Kirillow, Novgorod } \\
\text { region, Russia }\end{array}$ & Permian & $\sim 40$ & $\begin{array}{l}\text { Yakovlev, } \\
1926\end{array}$ & 1 & ? & Kowalewski et al., 2000 \\
\hline $\begin{array}{l}\text { Camarophoria superstes } \\
\text { (Rhynchonellida) }\end{array}$ & $\begin{array}{l}\text { Kirillow, Novgorod } \\
\text { region, Russia }\end{array}$ & Permian & $\sim 40$ & $\begin{array}{l}\text { Yakovlev, } \\
1926\end{array}$ & 1 & ? & Kowalewski et al., 2000 \\
\hline $\begin{array}{l}\text { Strophalosia horrescens } \\
\text { (Strophomenida) }\end{array}$ & $\begin{array}{l}\text { Kirillow, Novgorod } \\
\text { region, Russia }\end{array}$ & Permian & $\sim 40$ & $\begin{array}{l}\text { Yakovlev, } \\
1926\end{array}$ & - & ? & Kowalewski et al., 2000 \\
\hline $\begin{array}{l}\text { Productus hemisphaerium } \\
\text { (Strophomenida) }\end{array}$ & $\begin{array}{l}\text { Kirillow, Novgorod } \\
\text { region, Russia }\end{array}$ & Permian & $\sim 40$ & $\begin{array}{l}\text { Yakovlev, } \\
1926\end{array}$ & - & ? & Kowalewski et al., 2000 \\
\hline $\begin{array}{l}\text { Athyris pectinifera } \\
\text { (Spiriferida) }\end{array}$ & Sok River, Russia & Permian & $\sim 40$ & Hecker, 1965 & 1 & 1.2 & Kowalewski et al., 2000 \\
\hline
\end{tabular}




\begin{tabular}{|c|c|c|c|c|c|c|c|}
\hline $\begin{array}{l}\text { Derbyoides nebrascensis } \\
\text { (Strophomenida) }\end{array}$ & West Texas & Permian & $\sim 10$ & $\begin{array}{l}\text { Cooper \& } \\
\text { Grant, } 1974\end{array}$ & $1 ?$ & 1.4 & Kowalewski et al., 2000 \\
\hline Paucispinifera (Spiriferida) & West Texas & Permian & $\sim 10$ & $\begin{array}{l}\text { Cooper \& } \\
\text { Grant, } 1975\end{array}$ & $1 ?$ & 2.8 & Kowalewski et al., 2000 \\
\hline $\begin{array}{l}\text { Cooperina subcuneata } \\
\text { (Strophomenida) }\end{array}$ & West Texas & Permian & $\sim 10$ & $\begin{array}{l}\text { Cooper \& } \\
\text { Grant, } 1975\end{array}$ & $1 ?$ & 0.3 & Kowalewski et al., 2000 \\
\hline $\begin{array}{l}\text { Penicularis subcostata } \\
\text { (Strophomenida) }\end{array}$ & West Texas & Permian & $\sim 10$ & $\begin{array}{l}\text { Cooper \& } \\
\text { Grant, 1976a }\end{array}$ & $1 ?$ & ? & Kowalewski et al., 2000 \\
\hline $\begin{array}{l}\text { Craspedona newelli } \\
\text { (Strophomenida) }\end{array}$ & West Texas & Permian & $\sim 10$ & $\begin{array}{l}\text { Cooper \& } \\
\text { Grant, 1976a }\end{array}$ & $1 ?$ & $?$ & Kowalewski et al., 2000 \\
\hline $\begin{array}{ll}\text { Echinauris } & \text { lateralis } \\
\text { (Strophomenida) } & \end{array}$ & West Texas & Permian & $\sim 10$ & $\begin{array}{l}\text { Cooper \& } \\
\text { Grant, 1976a }\end{array}$ & 1 & 2.1 & Kowalewski et al., 2000 \\
\hline $\begin{array}{ll}\text { Rhamnaria } & \text { vinnula } \\
\text { (Strophomenida) }\end{array}$ & West Texas & Permian & $\sim 10$ & $\begin{array}{l}\text { Cooper \& } \\
\text { Grant, 1976a }\end{array}$ & 1 & 1.2 & Kowalewski et al., 2000 \\
\hline $\begin{array}{l}\text { Nudauris enigmatica } \\
\text { (Strophomenida) }\end{array}$ & West Texas & Permian & $\sim 10$ & $\begin{array}{l}\text { Cooper \& } \\
\text { Grant, 1976a }\end{array}$ & $1 ?$ & $?$ & Kowalewski et al., 2000 \\
\hline $\begin{array}{l}\text { Rugatia paraindica } \\
\text { (Strophomenida) }\end{array}$ & West Texas & Permian & $\sim 10$ & $\begin{array}{l}\text { Cooper \& } \\
\text { Grant, 1976a }\end{array}$ & 1 & 2.8 & Kowalewski et al., 2000 \\
\hline
\end{tabular}




\begin{tabular}{|c|c|c|c|c|c|c|c|}
\hline $\begin{array}{ll}\text { Rugatia } & \text { paraindica } \\
\text { (Strophomenida) } & \end{array}$ & West Texas & Permian & $\sim 10$ & $\begin{array}{l}\text { Cooper \& } \\
\text { Grant, 1976a }\end{array}$ & 1 & 2.6 & Kowalewski et al., 2000 \\
\hline $\begin{array}{l}\text { Xestosia schucherti } \\
\text { (Strophomenida) }\end{array}$ & West Texas & Permian & $\sim 10$ & $\begin{array}{l}\text { Cooper \& } \\
\text { Grant, 1976a }\end{array}$ & 1 & 1.8 & Kowalewski et al., 2000 \\
\hline $\begin{array}{l}\text { Peniculauris subcostata } \\
\text { (Strophomenida) }\end{array}$ & West Texas & Permian & $\sim 10$ & $\begin{array}{l}\text { Cooper \& } \\
\text { Grant, 1976a }\end{array}$ & $1 ?$ & ? & Kowalewski et al., 2000 \\
\hline $\begin{array}{ll}\text { Peniculauris costata } \\
\text { (Strophomenida) }\end{array}$ & West Texas & Permian & $\sim 10$ & $\begin{array}{l}\text { Cooper \& } \\
\text { Grant, 1976a }\end{array}$ & 1 & 2.6 & Kowalewski et al., 2000 \\
\hline $\begin{array}{l}\text { Anemonaria sublaevis } \\
\text { (Strophomenida) }\end{array}$ & West Texas & Permian & $\sim 10$ & $\begin{array}{l}\text { Cooper \& } \\
\text { Grant, 1976a }\end{array}$ & 1 & 1.4 & Kowalewski et al., 2000 \\
\hline $\begin{array}{ll}\text { Paucispinifera sulcata } \\
\text { (Strophomenida) }\end{array}$ & West Texas & Permian & $\sim 10$ & $\begin{array}{l}\text { Cooper \& } \\
\text { Grant, 1976a }\end{array}$ & 1 & 2.2 & Kowalewski et al., 2000 \\
\hline $\begin{array}{ll}\text { Siphonosia } & \text { alleni } \\
\text { (Strophomenida) } & \end{array}$ & West Texas & Permian & $\sim 10$ & $\begin{array}{l}\text { Cooper \& } \\
\text { Grant, 1976a }\end{array}$ & $1 ?$ & ? & Kowalewski et al., 2000 \\
\hline $\begin{array}{l}\text { Institella leonardensis } \\
\text { (Strophomenida) }\end{array}$ & West Texas & Permian & $\sim 10$ & $\begin{array}{l}\text { Cooper \& } \\
\text { Grant, 1976a }\end{array}$ & 1 & 1.6 & Kowalewski et al., 2000 \\
\hline $\begin{array}{l}\text { Dyoros (Dyoros) intrepidus } \\
\text { (Strophomenida) }\end{array}$ & West Texas & Permian & $\sim 10$ & $\begin{array}{l}\text { Cooper \& } \\
\text { Grant, 1976a }\end{array}$ & $1 ?$ & ? & Kowalewski et al., 2000 \\
\hline
\end{tabular}




\begin{tabular}{|c|c|c|c|c|c|c|c|}
\hline $\begin{array}{ll}\text { Rugaria } & \text { hessensis } \\
\text { (Strophomenida) } & \end{array}$ & West Texas & Permian & $\sim 10$ & $\begin{array}{l}\text { Cooper \& } \\
\text { Grant, 1976a }\end{array}$ & $1 ?$ & ? & Kowalewski et al., 2000 \\
\hline $\begin{array}{ll}\text { Amphipella } & \text { arcara } \\
\text { (Rhynchonellida) } & \end{array}$ & West Texas & Permian & $\sim 10$ & $\begin{array}{l}\text { Cooper \& } \\
\text { Grant, 1976a }\end{array}$ & $1 ?$ & 0.75 & Kowalewski et al., 2000 \\
\hline $\begin{array}{l}\text { Holosia } \\
\text { (Rhynchonellida) }\end{array}$ & West Texas & Permian & $\sim 10$ & $\begin{array}{l}\text { Cooper \& } \\
\text { Grant, 1976a }\end{array}$ & 1 & 1.8 & Kowalewski et al., 2000 \\
\hline $\begin{array}{ll}\text { Tautosia } & \text { fastigiata } \\
\text { (Rhynchonellida) } & \end{array}$ & West Texas & Permian & $\sim 10$ & $\begin{array}{l}\text { Cooper \& } \\
\text { Grant, 1976a }\end{array}$ & 1 & 1.4 & Kowalewski et al., 2000 \\
\hline $\begin{array}{l}\text { Petasmatherus } \\
\text { (Rhynchonellida) }\end{array}$ & West Texas & Permian & $\sim 10$ & $\begin{array}{l}\text { Cooper \& } \\
\text { Grant, 1976a }\end{array}$ & 1 & 1.8 & Kowalewski et al., 2000 \\
\hline $\begin{array}{l}\text { Stenoscisma } \\
\text { (Rhynchonellida) }\end{array}$ & West Texas & Permian & $\sim 10$ & $\begin{array}{l}\text { Cooper \& } \\
\text { Grant, 1976a }\end{array}$ & 1 & 0.8 & Kowalewski et al., 2000 \\
\hline $\begin{array}{l}\text { Stenoscisma } \\
\text { (Rhynchonellida) }\end{array}$ & West Texas & Permian & $\sim 10$ & $\begin{array}{l}\text { Cooper \& } \\
\text { Grant, 1976a }\end{array}$ & 1 & 0.8 & Kowalewski et al., 2000 \\
\hline $\begin{array}{l}\text { Stenoscisma } \\
\text { (Rhynchonellida) }\end{array}$ & West Texas & Permian & $\sim 10$ & $\begin{array}{l}\text { Cooper \& } \\
\text { Grant, 1976a }\end{array}$ & 1 & 1.6 & Kowalewski et al., 2000 \\
\hline $\begin{array}{l}\text { Stenoscisma } \\
\text { (Rhynchonellida) }\end{array}$ & West Texas & Permian & $\sim 10$ & $\begin{array}{l}\text { Cooper \& } \\
\text { Grant, 1976a }\end{array}$ & 1 & 1.2 & Kowalewski et al., 2000 \\
\hline
\end{tabular}




\begin{tabular}{|c|c|c|c|c|c|c|c|}
\hline $\begin{array}{ll}\text { Stenoscisma } & \text { fabarium } \\
\text { (Rhynchonellida) } & \end{array}$ & West Texas & Permian & $\sim 10$ & $\begin{array}{l}\text { Cooper \& } \\
\text { Grant, 1976a }\end{array}$ & 1 & 1.8 & Kowalewski et al., 2000 \\
\hline $\begin{array}{ll}\text { Stenoscisma } & \text { fabarium } \\
\text { (Rhynchonellida) } & \end{array}$ & West Texas & Permian & $\sim 10$ & $\begin{array}{l}\text { Cooper \& } \\
\text { Grant, 1976a }\end{array}$ & 1 & 3 & Kowalewski et al., 2000 \\
\hline $\begin{array}{ll}\text { Stenoscisma } & \text { oblisum } \\
\text { (Rhynchonellida) } & \end{array}$ & West Texas & Permian & $\sim 10$ & $\begin{array}{l}\text { Cooper \& } \\
\text { Grant, 1976a }\end{array}$ & $1 ?$ & 1.4 & Kowalewski et al., 2000 \\
\hline $\begin{array}{ll}\text { Stenoscisma } & \text { triquetrum } \\
\text { (Rhynchonellida) } & \end{array}$ & West Texas & Permian & $\sim 10$ & $\begin{array}{l}\text { Cooper \& } \\
\text { Grant, 1976a }\end{array}$ & $1 ?$ & 1 & Kowalewski et al., 2000 \\
\hline $\begin{array}{ll}\text { Torynechus } & \text { caelatus } \\
\text { (Rhynchonellida) }\end{array}$ & West Texas & Permian & $\sim 10$ & $\begin{array}{l}\text { Cooper \& } \\
\text { Grant, 1976a }\end{array}$ & $1 ?$ & 2.2 & Kowalewski et al., 2000 \\
\hline $\begin{array}{l}\text { Cartorhium chelomatum } \\
\text { (Spiriferida) }\end{array}$ & West Texas & Permian & $\sim 10$ & $\begin{array}{l}\text { Cooper \& } \\
\text { Grant, 1976a }\end{array}$ & $1 ?$ & 5.1 & Kowalewski et al., 2000 \\
\hline Eliva shumardi (Spiriferida) & West Texas & Permian & $\sim 10$ & $\begin{array}{l}\text { Cooper \& } \\
\text { Grant, 1976a }\end{array}$ & $1 ?$ & 1.3 & Kowalewski et al., 2000 \\
\hline $\begin{array}{l}\text { Neophricadothyris cordata } \\
\text { (Spiriferida) }\end{array}$ & West Texas & Permian & $\sim 10$ & $\begin{array}{l}\text { Cooper \& } \\
\text { Grant, 1976a }\end{array}$ & $1 ?$ & 1.7 & Kowalewski et al., 2000 \\
\hline Rallacosta actina (Spiriferida) & West Texas & Permian & $\sim 10$ & $\begin{array}{l}\text { Cooper \& } \\
\text { Grant, 1976a }\end{array}$ & 1 & 1.6 & Kowalewski et al., 2000 \\
\hline
\end{tabular}




\begin{tabular}{|c|c|c|c|c|c|c|c|}
\hline $\begin{array}{l}\text { Rallacosta } \\
\text { (Spiriferida) }\end{array}$ & West Texas & Permian & $\sim 10$ & $\begin{array}{l}\text { Cooper \& } \\
\text { Grant, 1976a }\end{array}$ & 1 & 2.8 & Kowalewski et al., 2000 \\
\hline $\begin{array}{ll}\text { Rallacosta laminata } \\
\text { (Spiriferida) }\end{array}$ & West Texas & Permian & $\sim 10$ & $\begin{array}{l}\text { Cooper \& } \\
\text { Grant, 1976a }\end{array}$ & 1 & 1.4 & Kowalewski et al., 2000 \\
\hline $\begin{array}{ll}\text { Composita enormis } \\
\text { (Spiriferida) }\end{array}$ & West Texas & Permian & $\sim 10$ & $\begin{array}{l}\text { Cooper \& } \\
\text { Grant, 1976a }\end{array}$ & $1 ?$ & 1.8 & Kowalewski et al., 2000 \\
\hline Composita pilula (Spiriferida) & West Texas & Permian & $\sim 10$ & $\begin{array}{l}\text { Cooper \& } \\
\text { Grant, 1976a }\end{array}$ & 1 & 1.2 & Kowalewski et al., 2000 \\
\hline $\begin{array}{l}\text { Composita mexicana } \\
\text { (Spiriferida) }\end{array}$ & West Texas & Permian & $\sim 10$ & $\begin{array}{l}\text { Cooper \& } \\
\text { Grant, 1976a }\end{array}$ & 1 & 0.4 & Kowalewski et al., 2000 \\
\hline $\begin{array}{l}\text { Composita parasulcata } \\
\text { (Spiriferida) }\end{array}$ & West Texas & Permian & $\sim 10$ & $\begin{array}{l}\text { Cooper \& } \\
\text { Grant, 1976a }\end{array}$ & $1 ?$ & 1.6 & Kowalewski et al., 2000 \\
\hline $\begin{array}{l}\text { Parenteletes } \\
\text { (Rhipidomellida) }\end{array}$ & West Texas & Permian & $\sim 10$ & $\begin{array}{l}\text { Cooper \& } \\
\text { Grant, 1976b }\end{array}$ & $1 ?$ & $?$ & Kowalewski et al., 2000 \\
\hline $\begin{array}{l}\text { Rhynchopora } \\
\text { (Uncertain) }\end{array}$ & West Texas & Permian & $\sim 10$ & $\begin{array}{l}\text { Cooper \& } \\
\text { Grant, 1976b }\end{array}$ & $1 ?$ & 1.1 & Kowalewski et al., 2000 \\
\hline $\begin{array}{l}\text { Metriolepis } \\
\text { (Spiriferinida) }\end{array}$ & West Texas & Permian & $\sim 10$ & $\begin{array}{l}\text { Cooper \& } \\
\text { Grant, 1976b }\end{array}$ & 1 & 1.6 & Kowalewski et al., 2000 \\
\hline
\end{tabular}




\begin{tabular}{|c|c|c|c|c|c|c|c|}
\hline $\begin{array}{lll}\text { Hustedia trita } & \text { trita } \\
\text { (Spiriferinida) } & & \\
\end{array}$ & West Texas & Permian & $\sim 10$ & $\begin{array}{l}\text { Cooper \& } \\
\text { Grant, 1976b }\end{array}$ & $1 ?$ & 1.1 & Kowalewski et al., 2000 \\
\hline $\begin{array}{ll}\text { Thedusia bucrenata } \\
\text { (Spiriferinida) }\end{array}$ & West Texas & Permian & $\sim 10$ & $\begin{array}{l}\text { Cooper \& } \\
\text { Grant, 1976b }\end{array}$ & 1 & 1.2 & Kowalewski et al., 2000 \\
\hline $\begin{array}{l}\text { Dielasma } \\
\text { (Terebratulida) }\end{array}$ & West Texas & Permian & $\sim 10$ & $\begin{array}{l}\text { Cooper \& } \\
\text { Grant, 1976b }\end{array}$ & $1 ?$ & 0.6 & Kowalewski et al., 2000 \\
\hline $\begin{array}{l}\text { Cryptacanthia } \\
\text { (Terebratulida) }\end{array}$ & West Texas & Permian & $\sim 10$ & $\begin{array}{l}\text { Cooper \& } \\
\text { Grant, 1976b }\end{array}$ & $1 ?$ & 0.6 & Kowalewski et al., 2000 \\
\hline $\begin{array}{l}\text { Disphenia } \\
\text { (Terebratulida) }\end{array}$ & $\begin{array}{l}\text { Hydra Island, } \\
\text { Greece }\end{array}$ & $\begin{array}{l}\text { Baisalia } \\
\mathrm{n}\end{array}$ & $\sim 35$ & Grant, 1988 & 1 & 1 & Kowalewski et al., 2000 \\
\hline $\begin{array}{l}\text { Disphenia } \\
\text { (Terebratulida) }\end{array}$ & $\begin{array}{l}\text { Hydra Island, } \\
\text { Greece }\end{array}$ & $\begin{array}{l}\text { Baisalia } \\
\mathrm{n}\end{array}$ & $\sim 35$ & Grant, 1988 & 1 & 0.6 & Kowalewski et al., 2000 \\
\hline $\begin{array}{l}\text { Disphenia } \\
\text { (Terebratulida) }\end{array}$ & $\begin{array}{l}\text { Hydra Island, } \\
\text { Greece }\end{array}$ & $\begin{array}{l}\text { Baisalia } \\
\mathrm{n}\end{array}$ & $\sim 35$ & Grant, 1988 & 1 & 0.6 & Kowalewski et al., 2000 \\
\hline $\begin{array}{l}\text { Disphenia } \\
\text { (Terebratulida) }\end{array}$ & $\begin{array}{l}\text { Hydra Island, } \\
\text { Greece }\end{array}$ & $\begin{array}{l}\text { Baisalia } \\
\mathrm{n}\end{array}$ & $\sim 35$ & Grant, 1988 & 1 & 0.4 & Kowalewski et al., 2000 \\
\hline $\begin{array}{l}\text { Disphenia } \\
\text { (Terebratulida) }\end{array}$ & $\begin{array}{l}\text { Hydra Island, } \\
\text { Greece }\end{array}$ & $\begin{array}{l}\text { Baisalia } \\
\mathrm{n}\end{array}$ & $\sim 35$ & Grant, 1988 & 1 & 0.4 & Kowalewski et al., 2000 \\
\hline
\end{tabular}




\begin{tabular}{|c|c|c|c|c|c|c|c|}
\hline Martinia & $\begin{array}{l}\text { Cathedral Mtn. } \\
\text { Fm., west Texas }\end{array}$ & Permian & $\sim 10$ & $\begin{array}{l}\text { Kowalewski et } \\
\text { al } 2005\end{array}$ & 10 & 1.9 & Kowalewski et al., 2005 \\
\hline Composita & $\begin{array}{l}\text { Cathedral Mtn. } \\
\text { Fm., west Texas }\end{array}$ & Permian & $\sim 10$ & $\begin{array}{l}\text { Kowalewski et } \\
\text { al } 2005\end{array}$ & 7 & 2 & Kowalewski et al., 2005 \\
\hline Composita & $\begin{array}{l}\text { Road Canyon } \\
\text { Fm., west Texas }\end{array}$ & Permian & $\sim 10$ & $\begin{array}{l}\text { Kowalewski et } \\
\text { al } 2005\end{array}$ & 5 & 1.7 & Kowalewski et al., 2005 \\
\hline Pinzonella illusa & Brazil & Permian & $\sim-60$ & $\begin{array}{l}\text { Kowalewski et } \\
\text { al } 2000\end{array}$ & 1 & 3.1 & Kowalewski et al 2000 \\
\hline Pinzonella illusa & Brazil & Permian & $\sim-60$ & $\begin{array}{l}\text { Kowalewski et } \\
\text { al } 2000\end{array}$ & 1 & 0.6 & Kowalewski et al 2000 \\
\hline Pinzonella illusa & Brazil & Permian & $\sim-60$ & $\begin{array}{l}\text { Kowalewski et } \\
\text { al } 2000\end{array}$ & 1 & 0.5 & Kowalewski et al 2000 \\
\hline Pinzonella illusa & Brazil & Permian & $\sim-60$ & $\begin{array}{l}\text { Kowalewski et } \\
\text { al } 2000\end{array}$ & 1 & 0.6 & Kowalewski et al 2000 \\
\hline Pinzonella illusa & Brazil & Permian & $\sim-60$ & $\begin{array}{l}\text { Kowalewski et } \\
\text { al } 2000\end{array}$ & 1 & 0.5 & Kowalewski et al 2000 \\
\hline Pinzonella illusa & Brazil & Permian & $\sim-60$ & $\begin{array}{l}\text { Kowalewski et } \\
\text { al } 2000\end{array}$ & 1 & 0.5 & Kowalewski et al 2000 \\
\hline
\end{tabular}




\begin{tabular}{|c|c|c|c|c|c|c|c|}
\hline Pinzonella illusa & Brazil & Permian & $\sim-60$ & $\begin{array}{l}\text { Kowalewski et } \\
\text { al } 2000\end{array}$ & 1 & 0.9 & Kowalewski et al 2000 \\
\hline Pinzonella illusa & Brazil & Permian & $\sim-60$ & $\begin{array}{l}\text { Kowalewski et } \\
\text { al } 2000\end{array}$ & 1 & 1.8 & Kowalewski et al 2000 \\
\hline Pinzonella illusa & Brazil & Permian & $\sim-60$ & $\begin{array}{l}\text { Kowalewski et } \\
\text { al } 2000\end{array}$ & 1 & 0.4 & Kowalewski et al 2000 \\
\hline Plesiocyprinella carinata & Brazil & Permian & $\sim-60$ & $\begin{array}{l}\text { Kowalewski et } \\
\text { al } 2000\end{array}$ & 1 & 2.4 & Kowalewski et al 2000 \\
\hline Plesiocyprinella carinata & Brazil & Permian & $\sim-60$ & $\begin{array}{l}\text { Kowalewski et } \\
\text { al } 2000\end{array}$ & 1 & 5.5 & Kowalewski et al 2000 \\
\hline Plesiocyprinella carinata & Brazil & Permian & $\sim-60$ & $\begin{array}{l}\text { Kowalewski et } \\
\text { al } 2000\end{array}$ & 1 & 3 & Kowalewski et al 2000 \\
\hline Plesiocyprinella carinata & Brazil & Permian & $\sim-60$ & $\begin{array}{l}\text { Kowalewski et } \\
\text { al } 2000\end{array}$ & 1 & 5.8 & Kowalewski et al 2000 \\
\hline Cowperesia anceps & Brazil & Permian & $\sim-60$ & $\begin{array}{l}\text { Kowalewski et } \\
\text { al } 2000\end{array}$ & 1 & 1.1 & Kowalewski et al 2000 \\
\hline Cowperesia anceps & Brazil & Permian & $\sim-60$ & $\begin{array}{l}\text { Kowalewski et } \\
\text { al } 2000\end{array}$ & 1 & 0.8 & Kowalewski et al 2000 \\
\hline
\end{tabular}




\begin{tabular}{|c|c|c|c|c|c|c|c|}
\hline Casterella gratiosa & Brazil & Permian & $\sim-60$ & $\begin{array}{l}\text { Kowalewski et } \\
\text { al } 2000\end{array}$ & 1 & 4.1 & Kowalewski et al 2000 \\
\hline Pinegathyris? & $\begin{array}{l}\text { southeastern } \\
\text { Alaska }\end{array}$ & Permian & $\sim 60$ & $\begin{array}{lll}\text { Rohr et al., } \\
2016 & & \end{array}$ & 1 & 2.5 & Rohr et al., 2016 \\
\hline Spiriferella & $\begin{array}{l}\text { southeastern } \\
\text { Alaska }\end{array}$ & Permian & $\sim 60$ & $\begin{array}{lll}\text { Rohr et al., } & \\
2016 & & \\
\end{array}$ & 1 & 2.5 & Rohr et al., 2016 \\
\hline \multicolumn{8}{|l|}{ Conclusive result } \\
\hline Taxa & Geographic area & Age & \multicolumn{2}{|c|}{ Frequency of drilling } & \multicolumn{2}{|l|}{ Reference } & \\
\hline brachiopods & West Texas & Permian & \multicolumn{2}{|l|}{$1.07 \%$} & \multicolumn{2}{|c|}{ Hoffmeister, 2002} & \\
\hline mollusks & West Texas & Permian & \multicolumn{2}{|l|}{$7.43 \%$} & \multicolumn{2}{|c|}{ Hoffmeister, 2003} & \\
\hline mollusks & Brazil & Permian & $0.57 \%$ & & $\begin{array}{l}\text { Kowalewski } \\
2000\end{array}$ & et al & \\
\hline Minysphenia conopia & Greece & Permian & $<1.5 \%$ & & Grant, 1988 & & \\
\hline
\end{tabular}

